\title{
Base Case and Perturbation Scenarios
}

\author{
E. Edmunds \\ J. Stewart \\ J. Watz
}

October 1, 1998

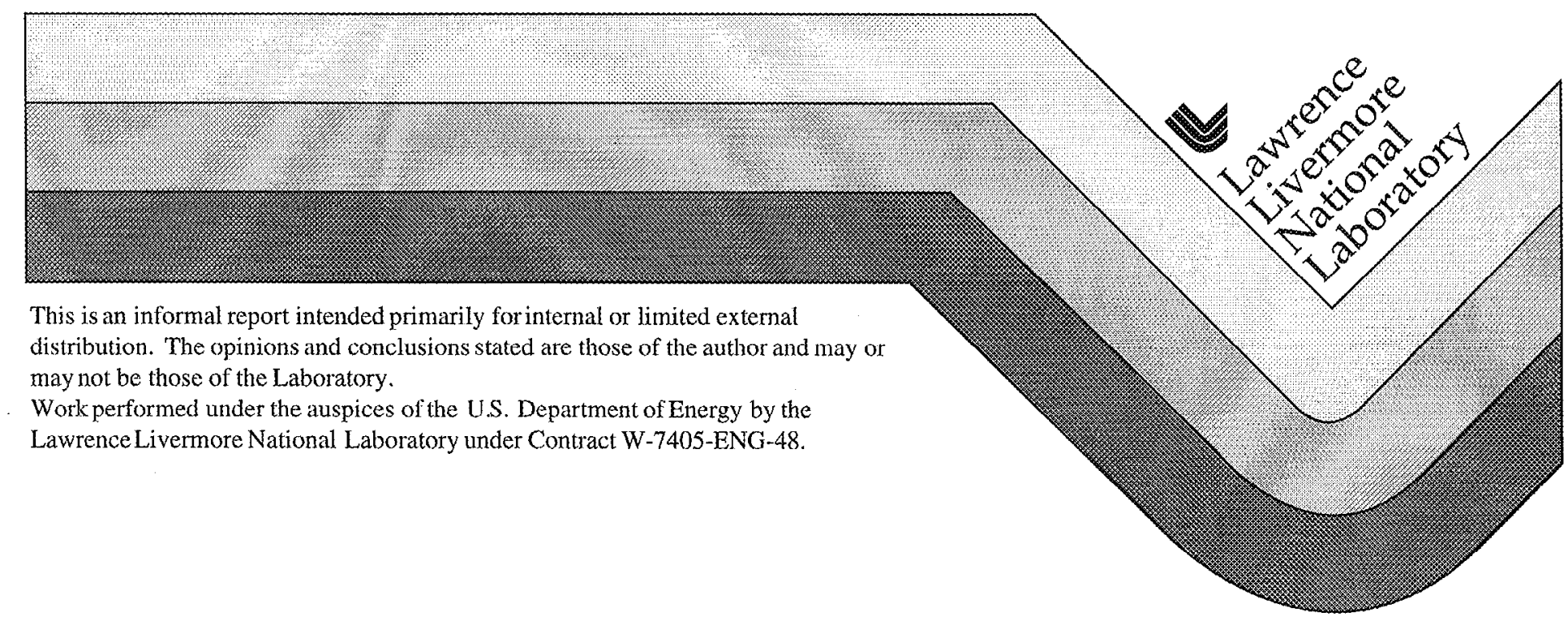




\section{DISCLAIMER}

This document was prepared as an account of work sponsored by an agency of the United States Government. Neither the United States Government nor the University of California nor any of their employees, makes any warranty, express or implied, or assumes any legal liability or responsibility for the accuracy, completeness, or usefulness of any information, apparatus, product, or process disclosed, or represents that its use would not infringe privately owned rights. Reference herein to any specific commercial product, process, or service by trade name, trademark, manufacturer, or otherwise, does not necessarily constitute or imply its endorsement, recommendation, or favoring by the United States Government or the University of California. The views and opinions of authors expressed herein do not necessarily state or reflect those of the United States Government or the University of California, and shall not be used for advertising or product endorsement purposes.

This report has been reproduced directly from the best available copy.

Available to DOE and DOE contractors from the Office of Scientific and Technical Information

P.O. Box 62, Oak Ridge, TN 37831

Prices available from (423) 576-8401

Available to the public from the National Technical Information Service

U.S. Department of Commerce

5285 Port Royal Rd.

Springfield, VA 22161 


\section{Base Case and Perturbation Scenarios}

October 1998

Prepared for the California Energy Commission

by

Dr. Thomas Edmunds, Jeffrey Stewart, and Jill Watz

University of California

Lawrence Livermore National Laboratory 


\section{TABLE OF CONTENTS}

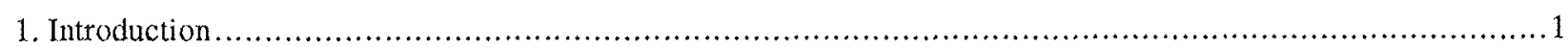

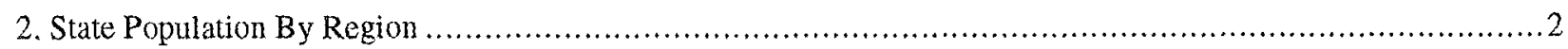

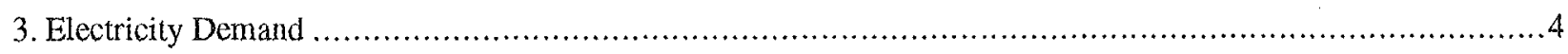

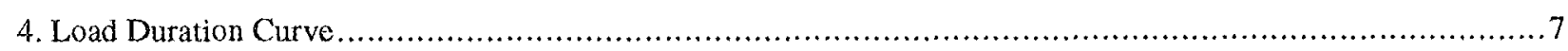

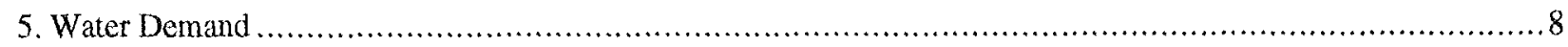

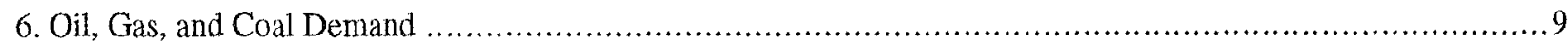

7. Oil, Gas, Coal, and Electricity Price Forecasts ..................................................................... 11

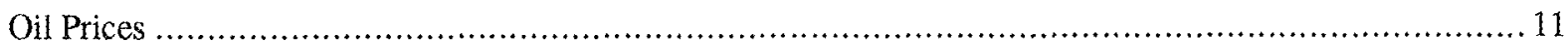

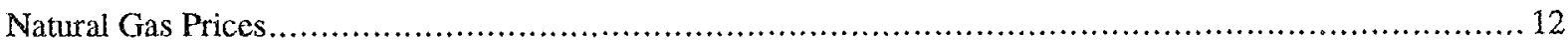

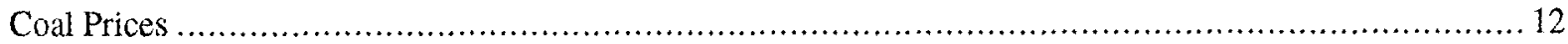

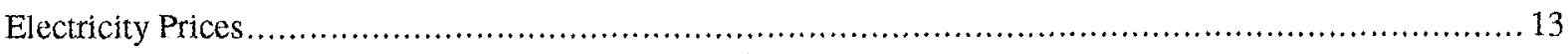

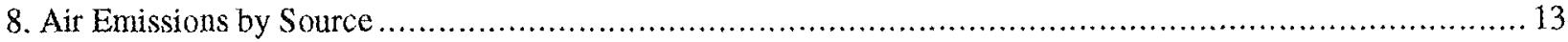

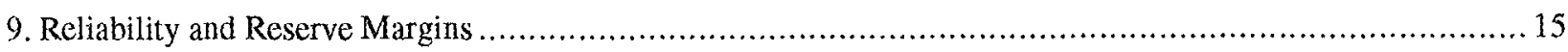

10. Competitive Market Performance/Market Structure ..................................................... 15

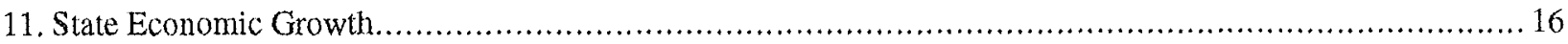

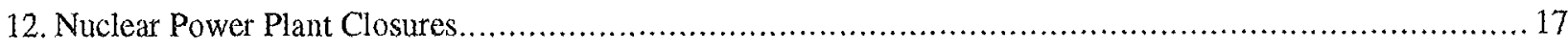

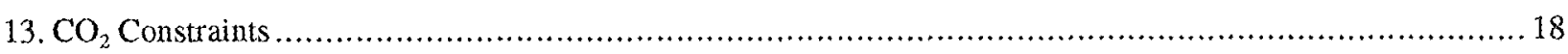

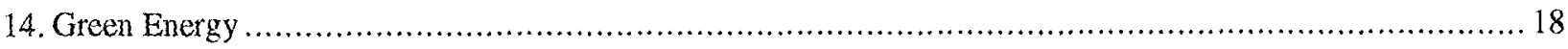

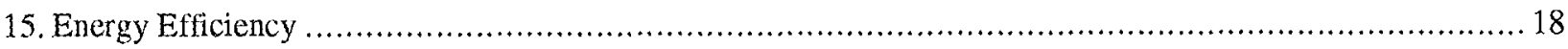





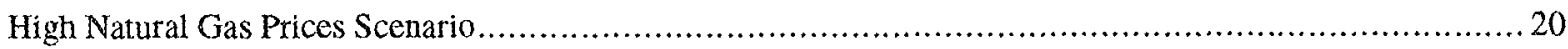

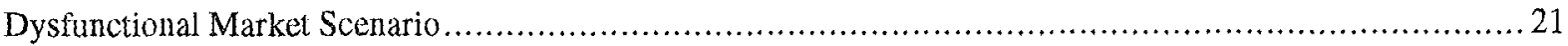

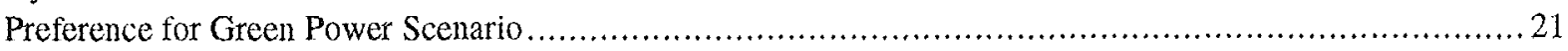

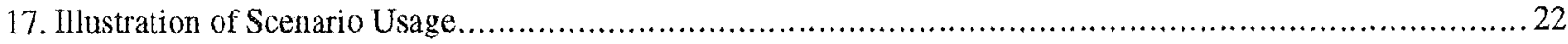

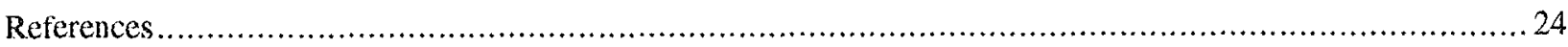




\section{TABLES}

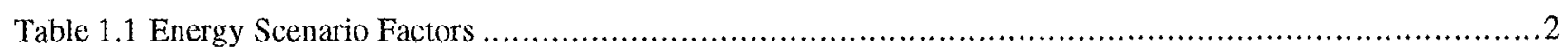

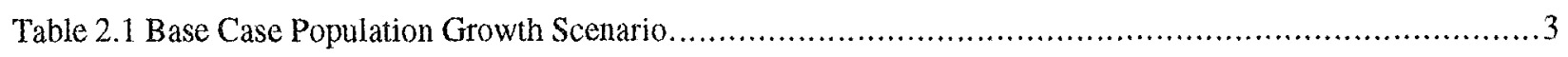

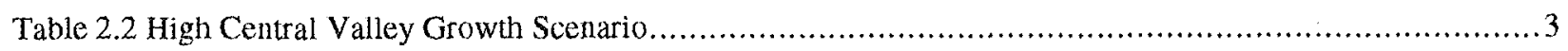

Table 6.1 U.S. Energy Demand in Quadrillion BTUs ............................................................. 9

Table 6.2 Natural Gas Supplies Available to California (TCF) ............................................... 10

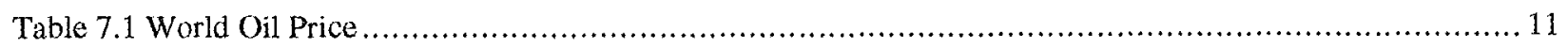

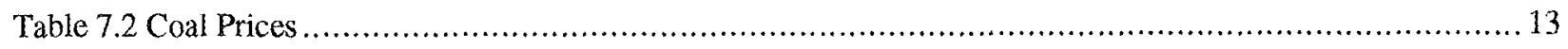

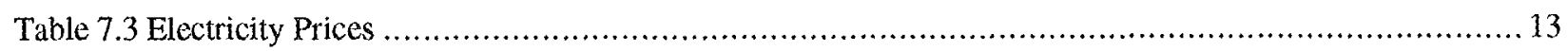

Table 12.1 Nuclear Plant Capacity and Closure Schedule ........................................................ 17

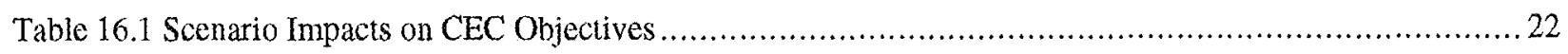

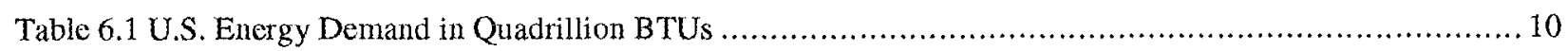

Table 6.2 Natural Gas Supplies Available to California (TCF) .................................................. 11

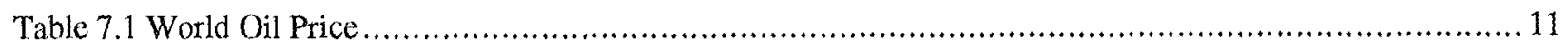

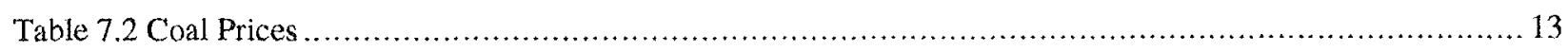

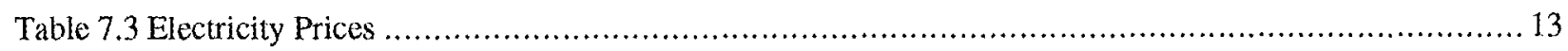

Table 12.1 Nuclear Plant Capacity and Closure Schedule..................................................... 17

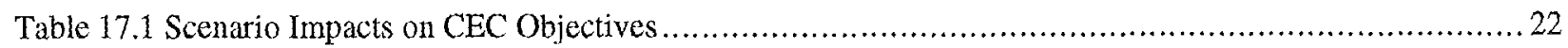

\section{FIGURES}

Figure 2.1 Comparison of Base Case and High Central Valley Growth Scenarios ......................................4

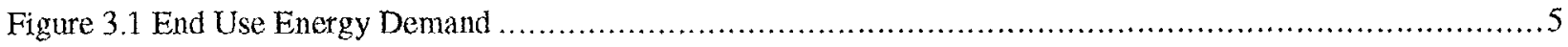

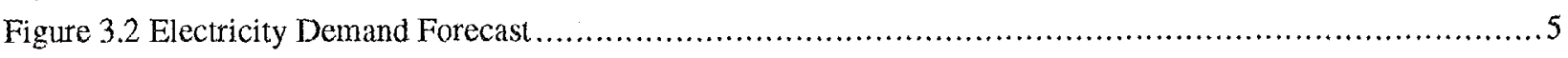

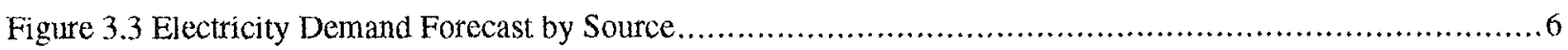

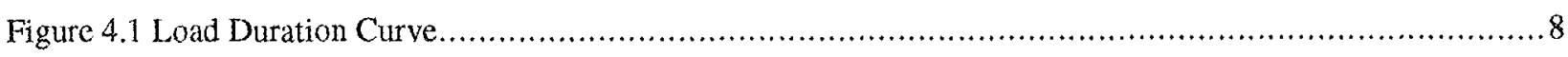



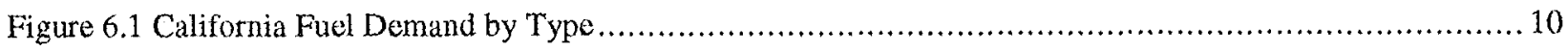

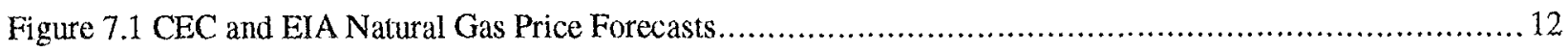

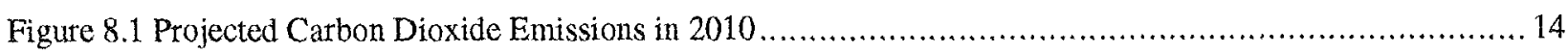

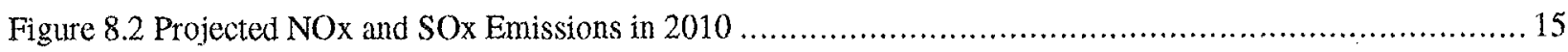

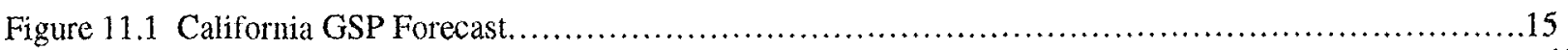

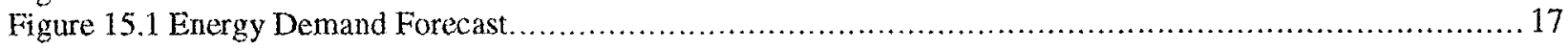






\section{INTRODUCTION}

As part of the Stage 2 Planning effort conducted by the California Energy Commission (CEC) staff for the Public Interest Energy Research Program (PIER), LLNL has developed energy scenarios to assist CEC staff in focusing their planning activities. The intent of the energy scenarios is to provide ideas for potential energy futures that can be used within a decision analysis framework to prioritize areas of $R \& D$ that meet the PIER objectives as required by Assembly Bill (AB) 1890 (enacted September 1996). The five PIER objectives are:

1) lower electricity prices

2) reduce environmental impact from electricity sources

3) help economic growth in California

4) ensure reliability of the grid

5) safety

Frequently, different decision inakers will have different expectations about the future evolution of the energy environment. This can lead to disagreements about the degree to which energy technologies will satisfy the objectives that are not based upon the merits of the technologies, but rather upon different expectations about the future energy environment. The characterization of the base case scenario provided in this report is intended to provide decision makers with a common framework for evaluating the importance of funding various PIER issue areas and the technologies that address them.

This report describes fourteen energy factors that could affect electricity markets in the future (demand, process, source mix, etc.). These fourteen factors are believed to have the most influence on the State's energy environment. A base case, or most probable, characterization is given for each of these fourteen factors over a twenty year time horizon. The base case characterization is derived from quantitative and qualitative information provided by State of California government agencies, where possible. Federal government databases are used where needed to supplement the California data. It is envisioned that a initial selection of issue areas will be based upon an evaluation of them under base case conditions.

For most of the fourteen factors, the report identifies possible perturbations from base case values or assumptions that may be used to construct additional scenarios. Only those perturbations that are plausible and would have a significant effect on energy markets are included in the table. The fourteen factors and potential perturbations of the factors are listed in Table 1.1. These perturbations can be combined to generate internally consistent combinations of perturbations relative to the base case. For example, a low natural gas price perturbation should be combined with a high natural gas demand perturbation.

The factor perturbations are based upon alternative quantitative forecasts provided by other institutions (the Department of Energy - Energy Information Administration in some cases), changes in assumptions that drive the quantitative forecasts, or changes in assumptions about the structure of the California energy markets. The perturbations are intended to be used for a qualitative reexamination of issue areas after an initial evaluation under the base case. The perturbation information would be used as a "tiebreaker;" to make decisions regarding those issue areas that were marginally accepted or rejected under the base case. If a quantitative scoring system for issue areas were applied under the base case, a tractable quantitative decision model incorporating scenarios and their likelihoods could be developed and applied in the decision process.

LLNL has developed four perturbation scenarios that address the following issues: 1) low economic growth, 2) high natural gas prices, 3) dysfunctional markets, and 4) a preference for green power. We have proposed a plausible scenario that addresses each issue for discussion and consideration by the CEC. 
In addition, we have provided an example application of the four perturbation scenarios in a qualitative framework for evaluation of issue areas developed for the PIER program. A description of each of the perturbation scenarios and a discussion of how they could effect decisions about today's R\&D funding is included. The scenarios attempt to cover a broad spectrum of plausible outcomes in a deregulated market environment. However, they are not a comprehensive and rigorously defined list of the most probable scenarios, but rather a qualitative inference based upon knowledge and expertise in the energy field.

Table 1.1 Energy Scenario Factors

\begin{tabular}{|l|l|}
\hline Description & Perturbation(s) \\
\hline 2. State Population by Region & Higher Growth in Central Valley \\
3. Load Duration Curve & Higher or Lower Growth (BEA) \\
4. Water Demand & Higher Peak-to-Average Load \\
5. Oil, Gas, Coal Demand & Extreme drought \\
6. Oil, Gas, Coal Electricity, Price & Higher or Lower Growth (EIA) \\
Forecasts & Higher or Lower Prices (EIA, CEC) \\
7. Air Emissions by Source & None \\
8. Reliahility and Reserve Margins & Lower Reliability \\
Market Structure & Monopolistic/Market Imperfections \\
10. State Economy Growth & Higher or Lower Growth \\
11. Nuclear Power Plant Closures & Plants Close in 2002 or Receive 10 Year \\
12. CO, Constraints & License Extension. \\
13. Green Energy & CO, Tax \\
14. Energy Efficiency & Consumers Willing to Pay Premium \\
\hline
\end{tabular}

\section{STATE POPULATION BY REGION}

Demand for electricity generation, transmission, and distribution will be affected by the number and location of people in the State. In general, movement of persons from the Coastal regions to the Central Valley will impose a larger air conditioning load on the system, affecting both load shape and the peak demand. Population and electricity demand growth in the Coastal urban areas will lead to the need for acquisition of additional land for transmission corridors and distribution facilities in areas that are already congested. Population growth in these two types of areas impose different requirements on energy systems, and suggest the need for different types of energy $R \& D$ projects.

Under the base case scenario, the State's population is assumed to increase at a compound annual growth rate of $1.41 \%$ over a twenty-year forecast period [DRI 98]. As shown in Table 2.1, the population data have been aggregated into five geographic regions. The historical data in Table 2.1 indicate that in the $1980 \mathrm{~s}$, population growth in the Central Valley was much higher than in other regions in the State. However, from 1990 to 1995, growth in the Central Valley slowed relative to other areas of California. The geographic distribution of the population shown in Table 2.1 assumes that this lower growth rate in the Central Valley persists throughout the forecast period. This is the hase case forecast.

A perturbation of this base case scenario is shown in Table 2.2. This scenario assumes that, due to the high cost of housing in coastal urban areas and other factors, the high growth rate observed for the Central Valley in the 1980 s is again realized. The scenario assumes the same total growth in the State population, 
but shifts some growth from the San Francisco Bay and LA/Orange/SD areas to the Central Valley. One third of the additional growth in the Central Valley is assumed to come from the San Francisco Bay area and the other two thirds of the additional Central Valley growth is assumed to come from the LA/Orange/SD area. This closely represents the relative populations of the two areas.

At the end of the forty-year period under the base case scenario (Table 2.1), the percent of the State's population living in the Central Valley increases from $14 \%$ to $16.4 \%$, or by approximately 6.8 million. If growth trends revert back to the 1980 's pattern, the Central Valley would see its population increase to $25.6 \%$ of the State's total, or approximately 10.7 million. Figure 2.1 illustrates the growth projections from Table 2.1 and Table 2.2, where HCV refers to the High Central Valley growth scenario. Population data are in thousands.

Table 2.1 Case Capulation Growth Scenario

\begin{tabular}{|c|c|c|c|c|c|c|}
\hline Year & Bay Area & Mountains & LA/Orange/SD Area & Central Valley & Other Coastal & Total \\
\hline $\mathbf{1 9 8 0}$ & $19.2 \%$ & $10.4 \%$ & $47.6 \%$ & $14.0 \%$ & $8.9 \%$ & $100.0 \%$ \\
$\mathbf{1 9 9 0}$ & $17.4 \%$ & $12.8 \%$ & $46.1 \%$ & $14.9 \%$ & $8.8 \%$ & $100.0 \%$ \\
$\mathbf{2 0 0 0}$ & $17.0 \%$ & $14.1 \%$ & $44.7 \%$ & $15.5 \%$ & $8.7 \%$ & $100.0 \%$ \\
$\mathbf{2 0 1 0}$ & $16.5 \%$ & $15.3 \%$ & $43.6 \%$ & $15.9 \%$ & $8.7 \%$ & $100.0 \%$ \\
$\mathbf{2 0 2 0}$ & $16.0 \%$ & $16.4 \%$ & $42.5 \%$ & $16.4 \%$ & $8.8 \%$ & $100.0 \%$ \\
\hline
\end{tabular}

Table 2.2 High Central Valley Growth Scenario

\begin{tabular}{|c|c|c|c|c|c|c|}
\hline Year & Bay Area & Mountains & LA/Orange/SD Area & Central Valley & Other Coastal & Total \\
\hline $\mathbf{1 9 8 0}$ & $19.2 \%$ & $10.4 \%$ & $47.6 \%$ & $14.0 \%$ & $8.9 \%$ & $100 \%$ \\
$\mathbf{1 9 9 0}$ & $17.4 \%$ & $12.8 \%$ & $46.1 \%$ & $14.9 \%$ & $8.8 \%$ & $100 \%$ \\
$\mathbf{2 0 0}$ & $16.2 \%$ & $14.1 \%$ & $43.1 \%$ & $17.9 \%$ & $8.7 \%$ & $100 \%$ \\
$\mathbf{2 0 1 0}$ & $14.7 \%$ & $15.3 \%$ & $40.0 \%$ & $21.3 \%$ & $8.7 \%$ & $100 \%$ \\
$\mathbf{2 0 2 0}$ & $12.9 \%$ & $16.4 \%$ & $36.4 \%$ & $25.6 \%$ & $8.8 \%$ & $100 \%$ \\
\hline
\end{tabular}




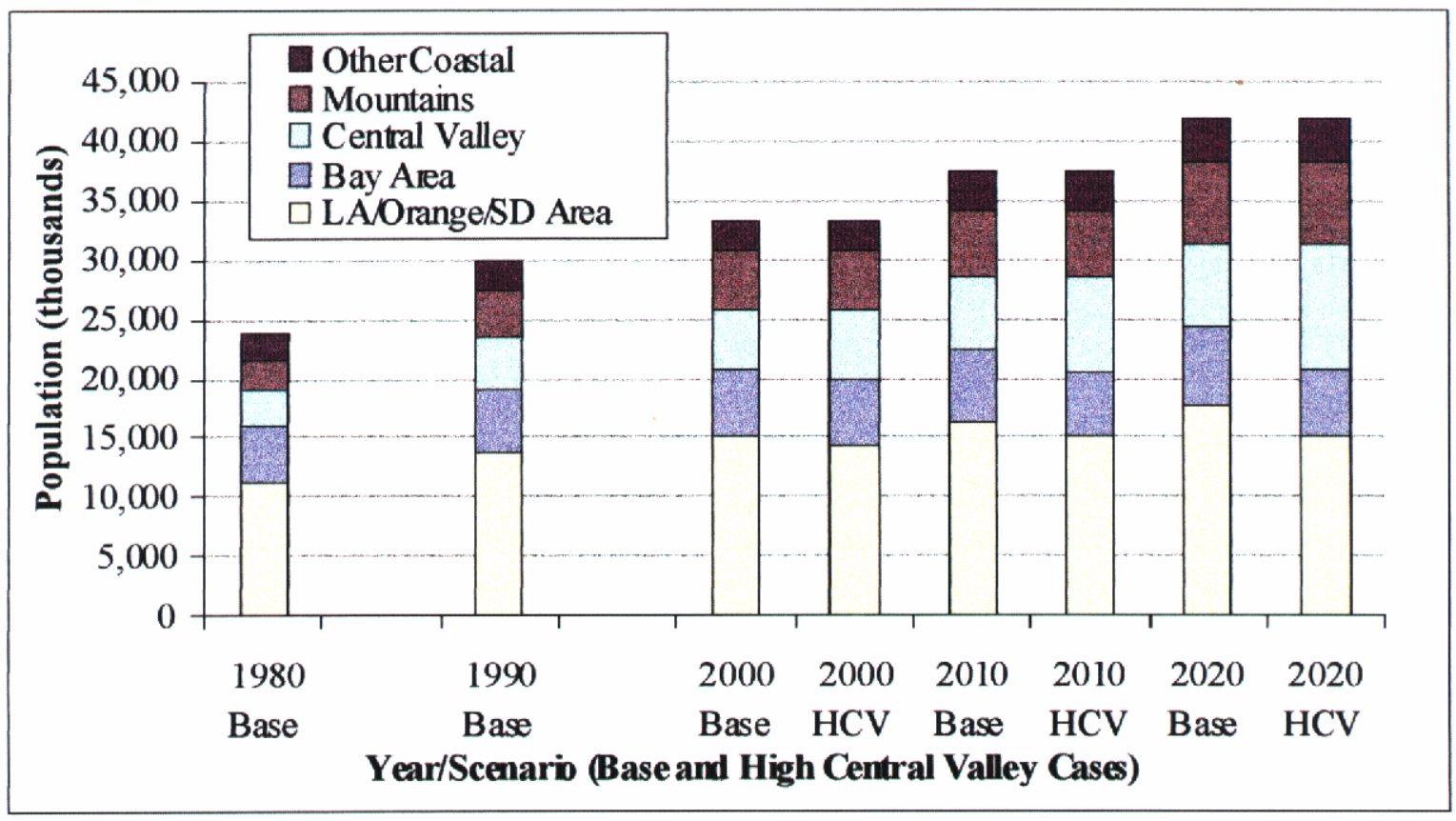

Figure 2.1 Comparison of Base Case and High Central Valley (HCV) Growth Scenarios

\section{ELECTRICITYDEMAND}

The transportation sector dominates end use energy demand in California. Although very little of this energy demand is currently met by electrical energy, transportation represents a large potential market for electrical energy. Moreover, the State's mandate for zero emission vehicles will likely accelerate the use of electricity for transportation.

As indicated by the data in Figure 3.1, energy demand for the transportation sector is not expected to grow significantly, from 2178 trillion BTUs/yr in 1994 to 2301 trillion BTUs/yr in 2013, or by 6\% over this 20 year time frame [CEC 98a]. By contrast, end use energy demand in the commercial sector is expected to grow by $40 \%$ over this 20 -year period, from 465 trillion BTUs/yr to 652 trillion BTUs/yr. Demands in the residential and industrial sectors are projected to grow by approximately $20 \%$ ( 779 trillion BTUs/yr to 932 trillion BTUs/yr) and 14\% (1447 trillion BTUs/yr to 1648 trillion BTUs/yr), respectively. The sum of energy demands over all sectors is expected to increase by approximately $14 \%$ over the 20-year period (4,868 trillion BTUs/yr to 5,534 trillion BTUs/yr). This represents a compound annual growth rate of just over $0.6 \%$. 


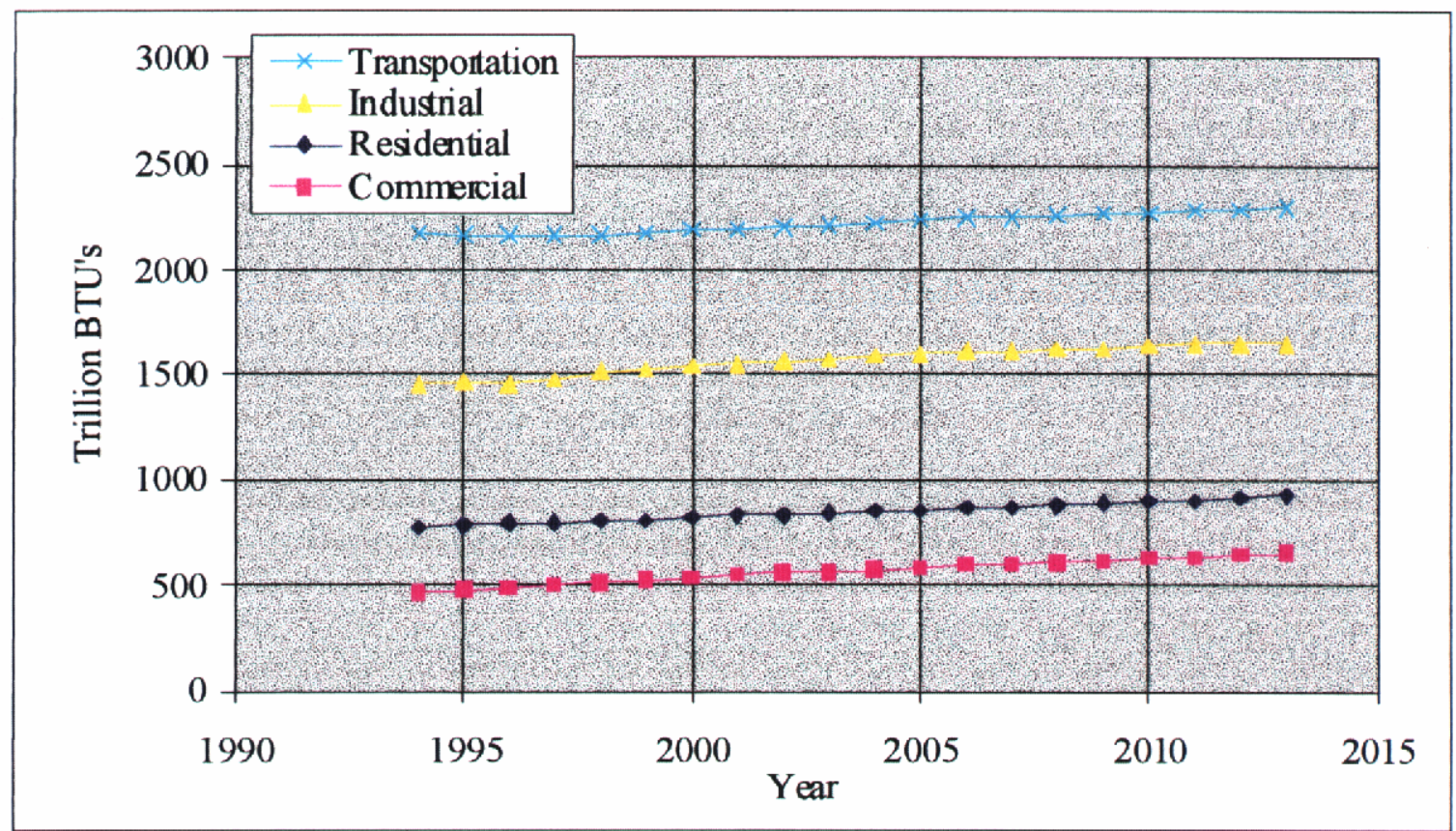

Figure 3.1 End Use Energy Demand

Base case values for State electrical energy demand were developed using data from the Bureau of Economic Analysis (BEA) and the CEC. Using BEA historical and projected economic data, LLNL economic perturbations (see Section 11), and CEC historic electrical energy generation, we developed a regression model and produced the forecast shown in Figure 3.2 [BEA 97a and CEC 98b]. By the year 2045 , the demands under these three scenarios range from 382,711 to 583,388 million $\mathrm{KWh} / \mathrm{yr}$.

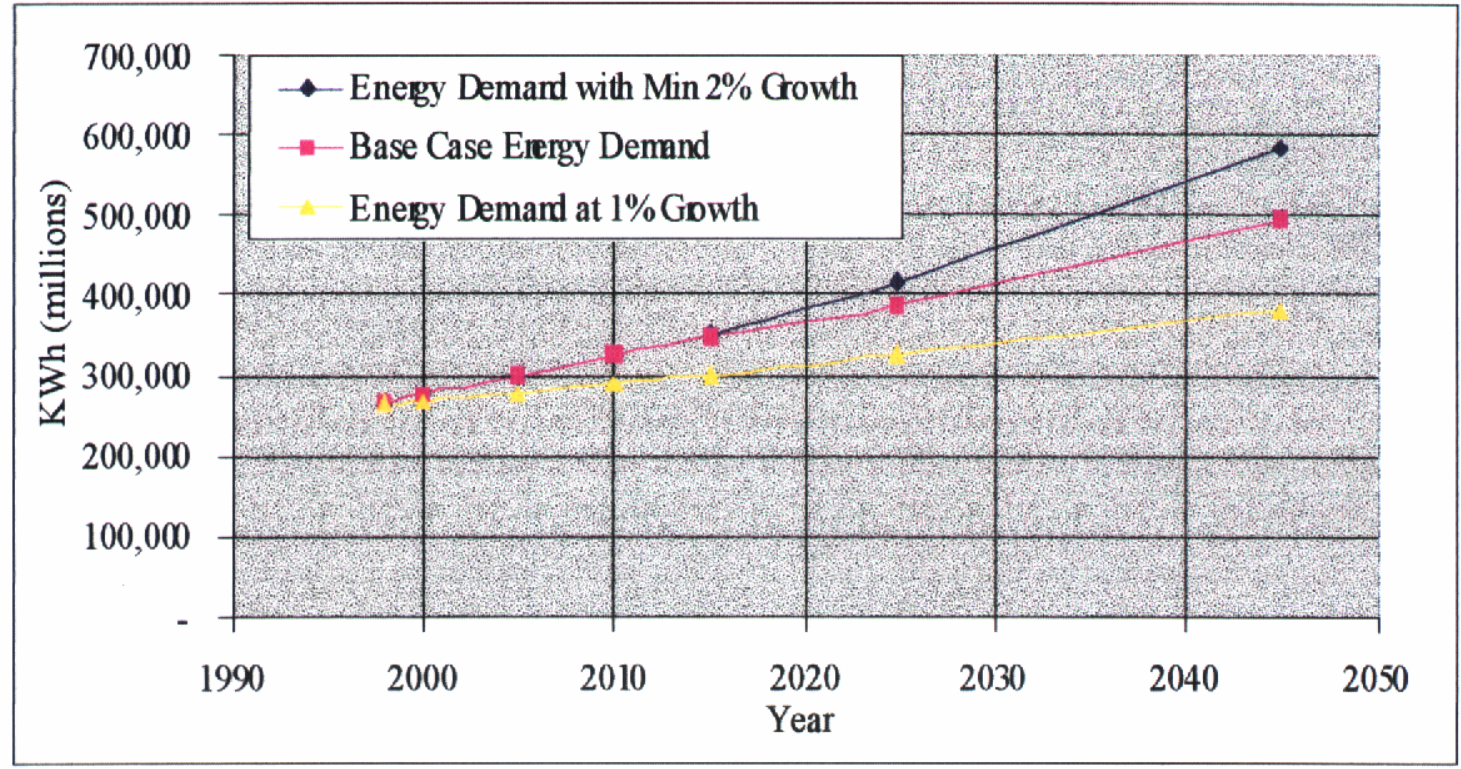

Figure 3.2 Electricity Demand Forecast 
Figure 3.3 shows the base case electricity production forecast by generation source. According to this projection, the State of California becomes heavily reliant upon natural gas for electricity generation by the year 2013 ( $51 \%$ of the generating mix). This "fuel switching" from current sources to natural gas, while significant in the market place, raises other issues when considered in terms of dependence on a single source with unknown or limited supplies located primarily outside the State.

The power generation from a contribution of coal, nuclear, biomass, and hydro remain relatively constant over this period of time. Slight increases in solar and wind generation are projected for the base case scenario.

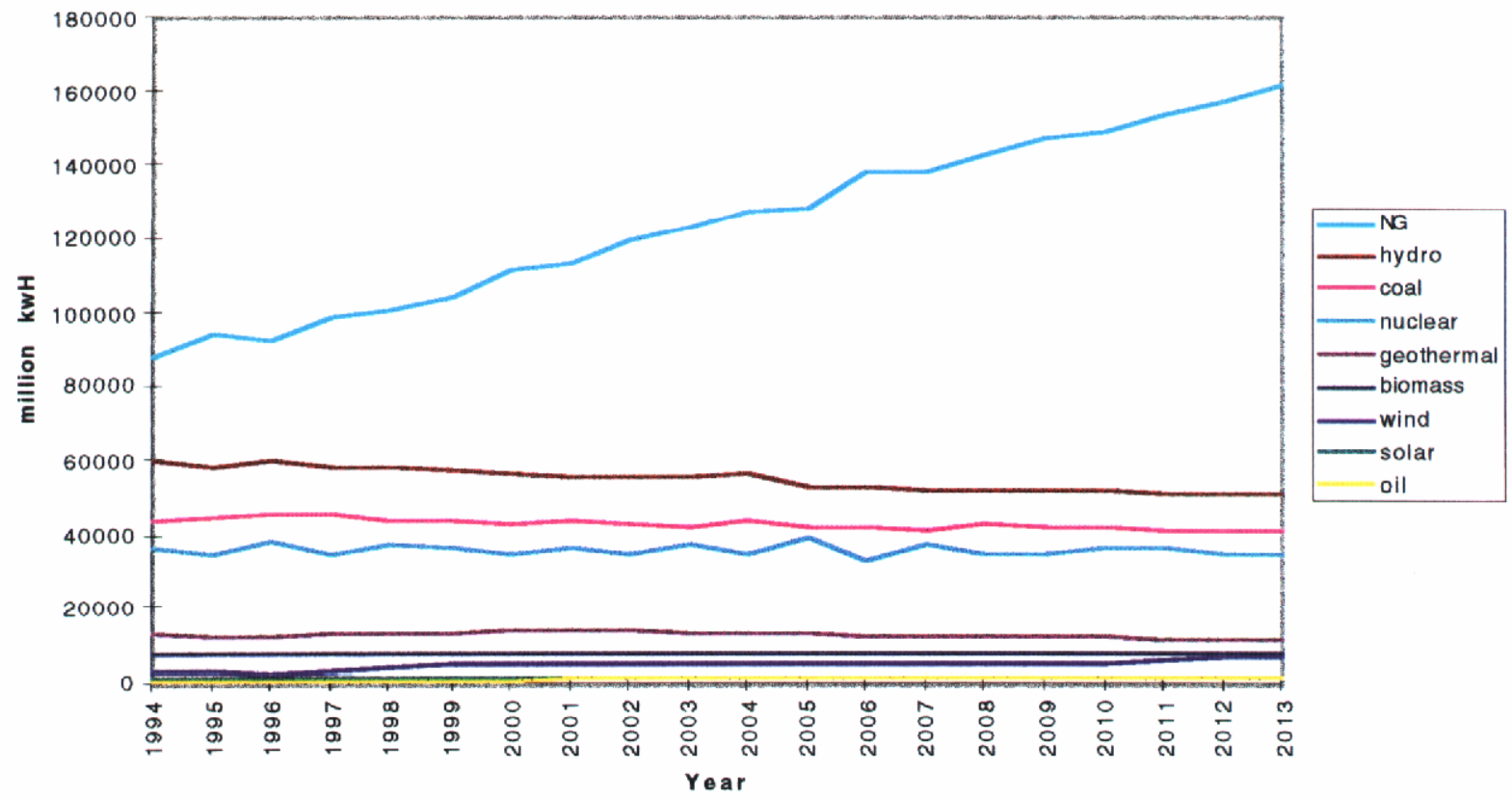

Figure 3.3 Electricity Demand Forecast by Source

As a perturbation to this base case, one could consider increases over the current level of government subsidies for renewable resources, and a minimum quota on the electricity generated using renewable resources in order to diversify the generating mix and to reduce emissions. For example, contributions from biomass, wind, and solar could be increased by a factor of three, to $17 \%$ of the total generation. It is assumed that this increase in renewable generation will be offset by decreases in generation with natural gas, which will then account for $41 \%$ of generation in the year 2013. All others generation resources remain the same as the base case. Demand projections under this perturbation scenario are shown in Figure 3.4. 


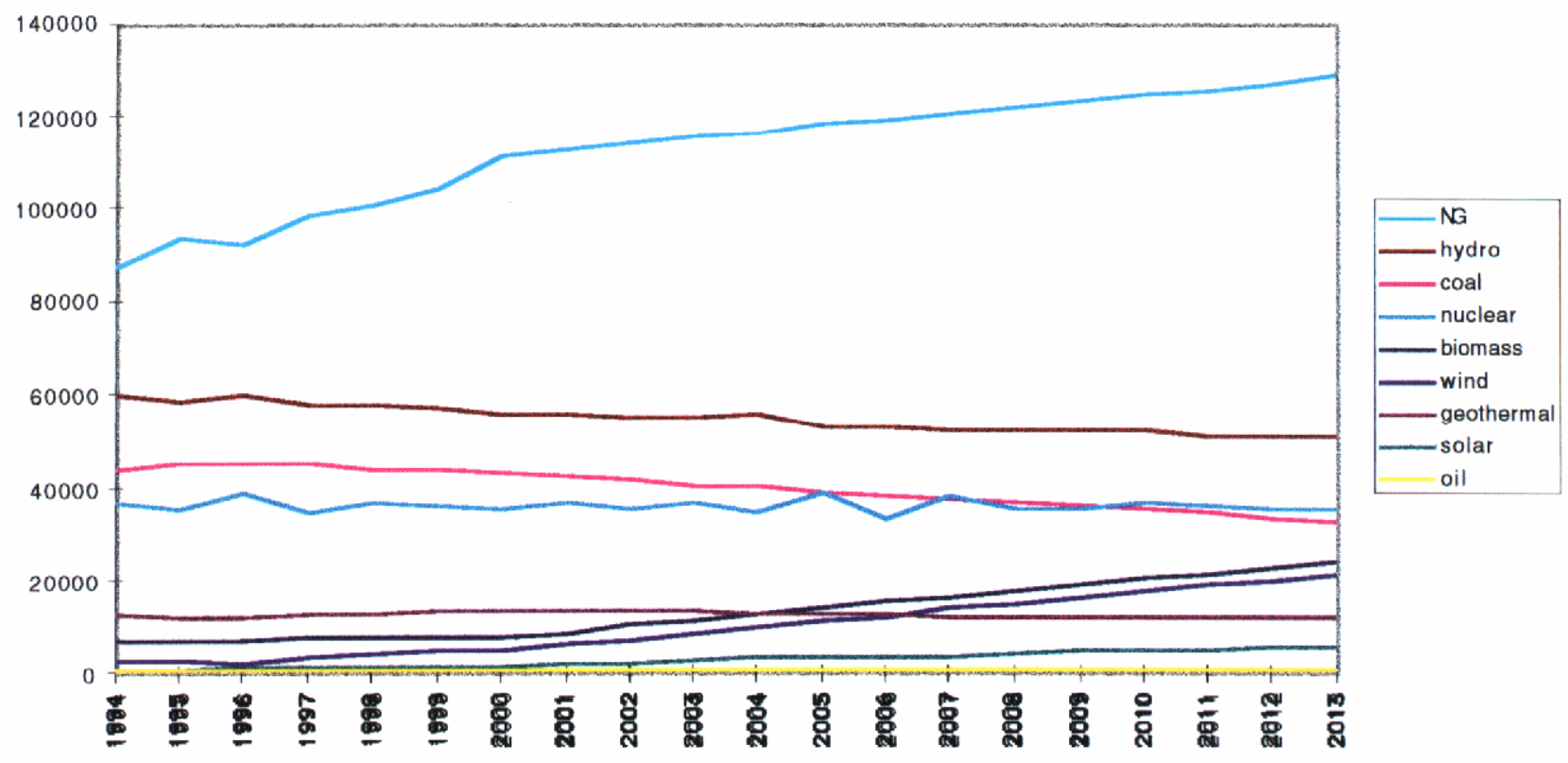

Figure 3.4 Electricity Demand by Source with 3x Renewables

\section{LOAD DURATION CURVE}

Load duration curves for Pacific Gas and Electric, San Diego Gas and Electric, and Southern California Edison are shown in Figure 4.1 [CEC 96a]. The curves, which display 1996 load data, are assumed to hold throughout the forecast period for the base case. For some of the perturbations about the base case, such as higher population growth in the Central Valley, the load duration curves are assumed to become more peaked (i.e., have a higher peak-to-average load ratio). 


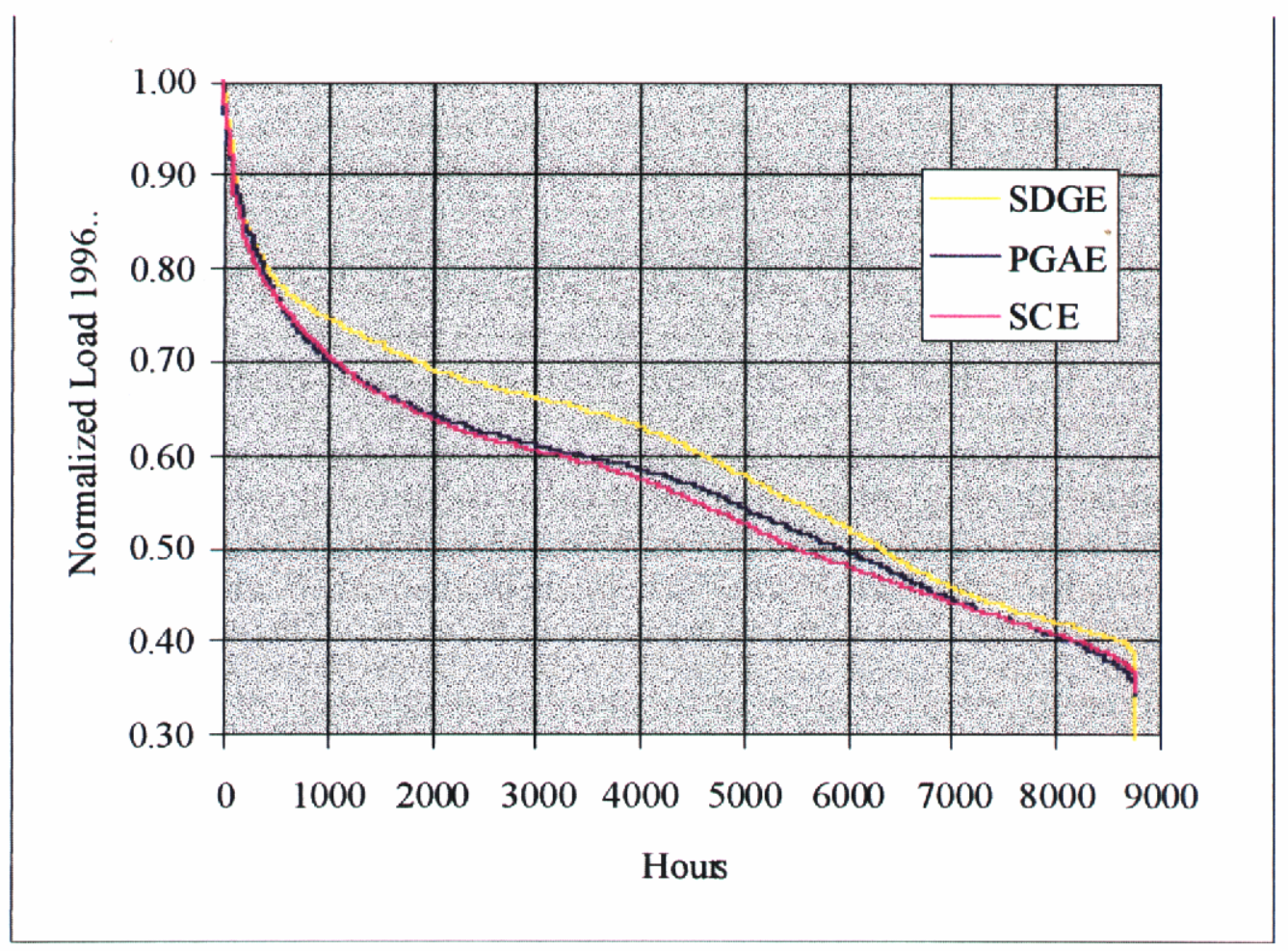

Figure 4.1 Load Duration Curve

\section{WATER DEMAND}

Historical average water allocation, and allocation during drought years are shown in Figure 5.1 [CDWR 98]. The California Department of Water Resources estimates that the 1991 drought year scenario has a recurrence frequency of once in 20 years (a 5 percent probability of occurring in any given year). The base case scenario presumes the occurrence of one drought, similar to that experienced in 1991, during the 20 year planning horizon.

Depending on the geographic location of a drought, it may decrease or increase demand for pumping power. For example, if less water is available to pump, lower electricity demand will be realized. Conversely, if more ground water needs to be pumped because areas depending on surface water are stricken by drought, then more energy would be needed. In addition, a drought in an area where hydropower is generated would lower the energy supply of that source. This would also occur at a time when air conditioning demand is increasing.

One possible extreme condition that was realized in at least one area of California during the last major drought is the use of desalination technology for supplemental water supply. In coastal areas, desalination may become more practical as the technology improves and costs continue to decline. However, the technology is very electricity-intensive and could pose new load requirements for coastal areas in the future. The perturbation of this factor from the base case presumes the need for supplemental water supplies in some coastal regions that would have to be met by energy-intensive solutions such as desalination or pumping over long distances. 


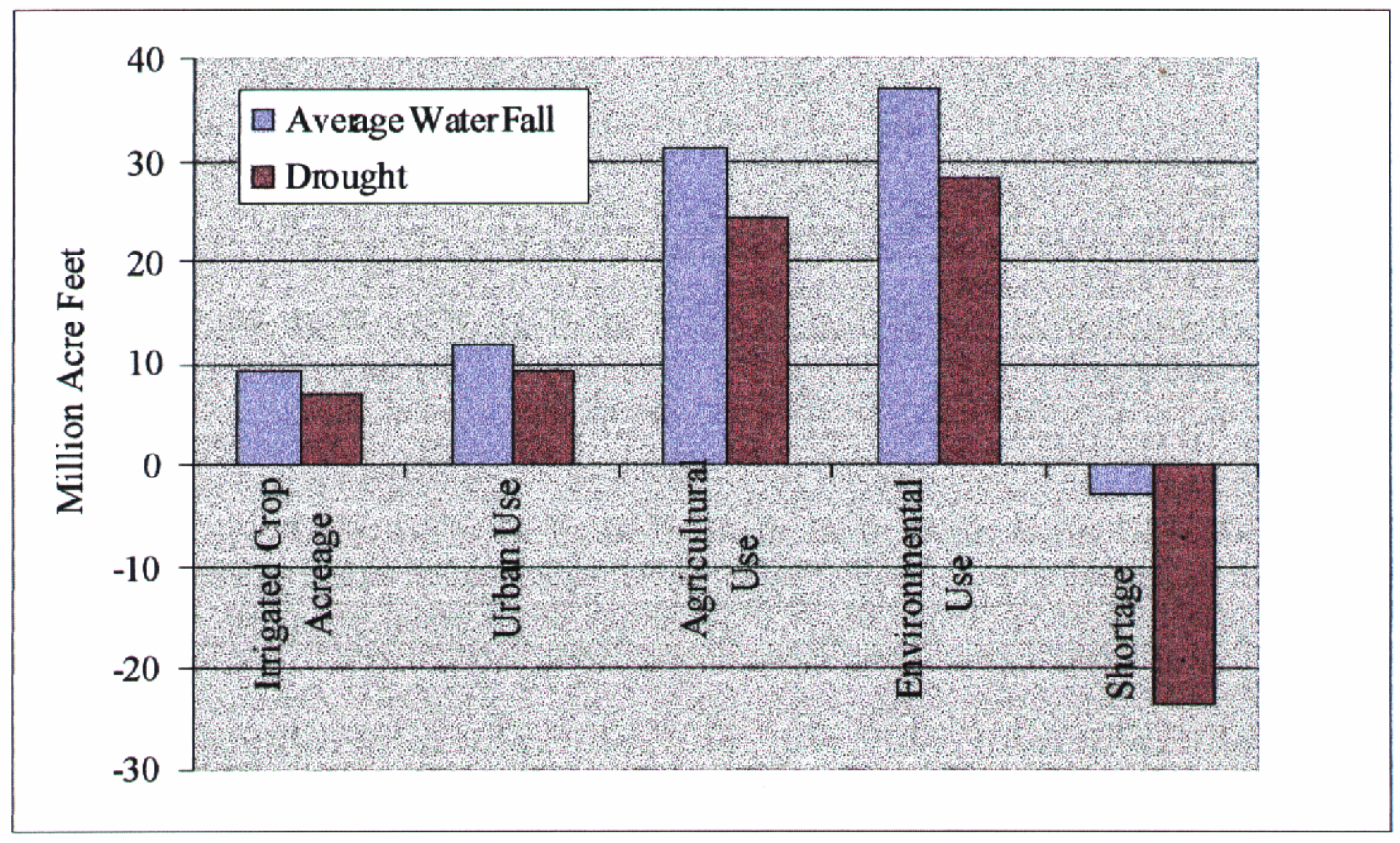

Figure 5.1 Water Demand

\section{OIL, GAS, AND COAL DEMAND}

U.S. demand for oil, natural gas, and coal is shown in Table 6.1 [DOE-EIA 98]. The data for the reference scenario indicate that demand for oil and related petroleum products will grow from 36.01 quads per year in 1996 to 47.64 quads per year in 2020 , or $32 \%$. This corresponds to a compound annual growth rate of $1.2 \%$. Growth rates for other scenarios range from $0.7 \%$ per year to $1.6 \%$ per year.

The demand for natural gas in the U.S. is expected to grow at a higher rate than the demand for petroleum. For the reference case, demand is expected to grow from 22.60 quads in 1996 to 33.06 quads in the year 2020, a $46 \%$ increase. This corresponds to a compound annual growth rate of $1.6 \%$. Growth rates for other scenarios range from $1.2 \%$ per year to $1.9 \%$ per year.

Demand for coal in the U.S. is expected to grow at a lower rate than the demand for oil and natural gas. The reference scenario predicts that demand for coal will grow from 20.90 quads per year in 1996 to 25.61 quads per year in 2020 , or $23 \%$. This corresponds to a compound annual growth rate of $0.9 \%$. Growth rates for other scenarios range from $0.4 \%$ per year to $1.3 \%$ per year. 
Table 6.1 U.S. Energy Demand in Quadrillion BTUs

\begin{tabular}{|c|c|c|c|c|c|c|c|}
\hline & 1995 & 1996 & \multicolumn{5}{|c|}{2020} \\
\hline & & & Reference & $\begin{array}{l}\text { Low } \\
\text { Economic } \\
\text { Growth }\end{array}$ & $\begin{array}{l}\text { High } \\
\text { Economic } \\
\text { Growth }\end{array}$ & $\begin{array}{l}\text { Low } \\
\text { World } \\
\text { Oil } \\
\text { Prices }\end{array}$ & $\begin{array}{l}\text { High } \\
\text { World } \\
\text { Oil } \\
\text { Prices }\end{array}$ \\
\hline $\begin{array}{l}\text { Petroleum } \\
\text { Products }\end{array}$ & 34.74 & 36.01 & 47.64 & 42.65 & 52.31 & 50.02 & 46.12 \\
\hline Natural gas & 22.18 & 22.60 & 33.06 & 30.19 & 35.43 & 32.00 & 33.69 \\
\hline Coal & 19.96 & 20.90 & 25.61 & 23.08 & 28.34 & 25.71 & 25.67 \\
\hline
\end{tabular}

In contrast, the CEC projects lower growth in demand for oil, gas, and coal in California. Oil, gas, and coal demand growth for the state of California is shown in Figure 6.1 [CEC 98c]. The demands for oil, gas, and coal in California are expected to grow at annual rates of $0.4 \%, 0.8 \%$ and $0.0 \%$, respectively.

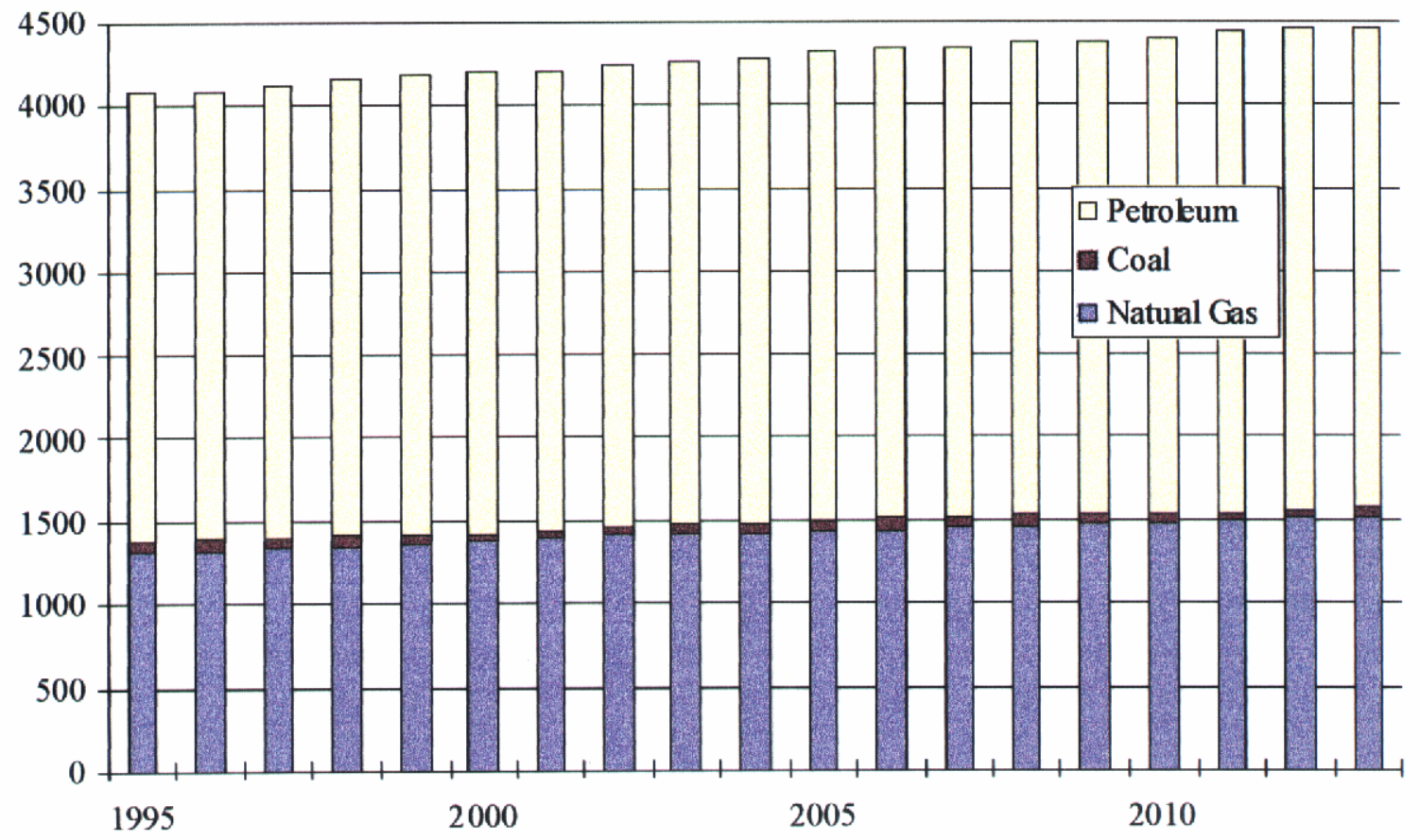

Figure 6.1 California Fuel Demand by Type

Finally, natural gas production available to U.S. markets has been estimated by the CEC. Production estimates are shown below in Table 6.2. As indicated by the data in the table, the total supply of natural gas available to California increases from 2.157 TCF in 1994 to 2.852 TCF in 2019. This increase corresponds to a compound annual growth rate of $1.1 \%$. Note that this supply growth rate exceeds California's demand growth rate of $0.8 \%$ per year. 
Table 6.2 Natural Gas Supplies Available to California (TCF)

\begin{tabular}{|l|l|l|l|l|l|l|}
\hline Producing Region & $\mathbf{1 9 9 4}$ & $\mathbf{1 9 9 9}$ & $\mathbf{2 0 0 4}$ & $\mathbf{2 0 0 9}$ & $\mathbf{2 0 1 4}$ & $\mathbf{2 0 1 9}$ \\
\hline Califoriia & 0.311 & 0.379 & 0.386 & 0.429 & 0.430 & 0.415 \\
Southwest & 1.013 & 0.866 & 1.087 & 0.966 & 1.013 & 1.028 \\
Rocky Mountains & 0.243 & 0.180 & 0.252 & 0.428 & 0.516 & 0.602 \\
Canada & 0.590 & 0.635 & 0.678 & 0.751 & 0.772 & 0.807 \\
Total Supply Avaliable to California & 2.157 & 2.060 & 2.403 & 2.575 & 2.731 & 2.852 \\
\hline
\end{tabular}

The base case scenario presumes the $\mathrm{CEC}$ estimates of demand growth. Growth rates in the EIA basc and high scenarios are suggested as perturbations.

\section{OIL, GAS, COAL, AND ELECTRICITYPRICE HORECASTS}

\section{Oil prices}

World oil prices for the base case, high, and low price scenarios are show in Table 7.1 [DOE-EIA 98, pg. 7]. As indicated by the base case data in the table, world oil prices are expected to reach $\$ 22.32$ per barrel by the year 2020 (in 1996 dollars). Relative to the current world oil price of approximately $\$ 15$ per barrel, this is a real price escalation rate of $1.8 \%$ per year. The DOE-EIA oil price projections for the year 2020 range from a low of $\$ 14.43 / \mathrm{bbl}$ to a high of $\$ 28.71 / \mathrm{bbl}$; a factor of two variation in price.

Table 7.l World Oil Price

\begin{tabular}{|l|l|}
\hline Year/scenario & Price $(\$ / \mathbf{b b l})$ \\
\hline 1995 & 17.58 \\
1996 & 20.48 \\
2020 Base case & 22.32 \\
$2020 /$ Low economic growth & 21.24 \\
2020 High economic growth & 23.44 \\
$2020 /$ Low world oil price & 14.43 \\
2020 Hitgh wolld oil price & 28.71 \\
\hline
\end{tabular}

Because oil is not used for electricity generation in the state of California, world oil prices do not directly affect the cost or supply of electricity in the state. However, high oil prices and California public policy requiring zero emission vehicles could accelerate the rate of market penetration of electric vehicles or other alternative fueled vehicles that may effect the characteristics for electric power demand in the state.

For example, the demand cycle for electric power to charge vehicles for the daily commute may lead to a high peak in electric power demand early in the morning. Under such circumstances, energy storage technologies for the grid-mor vehicle recharging technologies that distributed the load over the early morning hours when demand from other sources is low-would be beneficial. 


\section{Natural Gas Prices}

Natural gas price forecasts for the base case, high, and low price scenarios are shown in Figure 7.1 [CEC 97a, DOE-EIA 98]. As indicated by the data in the figure, the CEC projects that natural gas prices in California will rise from $\$ 1.83 / \mathrm{MCF}$ in 1999 to $\$ 2.62 / \mathrm{MCF}$ in 2019 [CEC 97b]. This is a real price escalation rate of $1.8 \%$ per year. This CEC price trajectory is initially below the EIA base case forecast, but converges to the EIA forecast in later years. As indicated by the data in the figure, the EIA price projection in the year 2020 is not very sensitive to the assumptions in the high and low world oil price scenarios, but is very sensitive to the assumptions in the high and low economic growth scenarios.

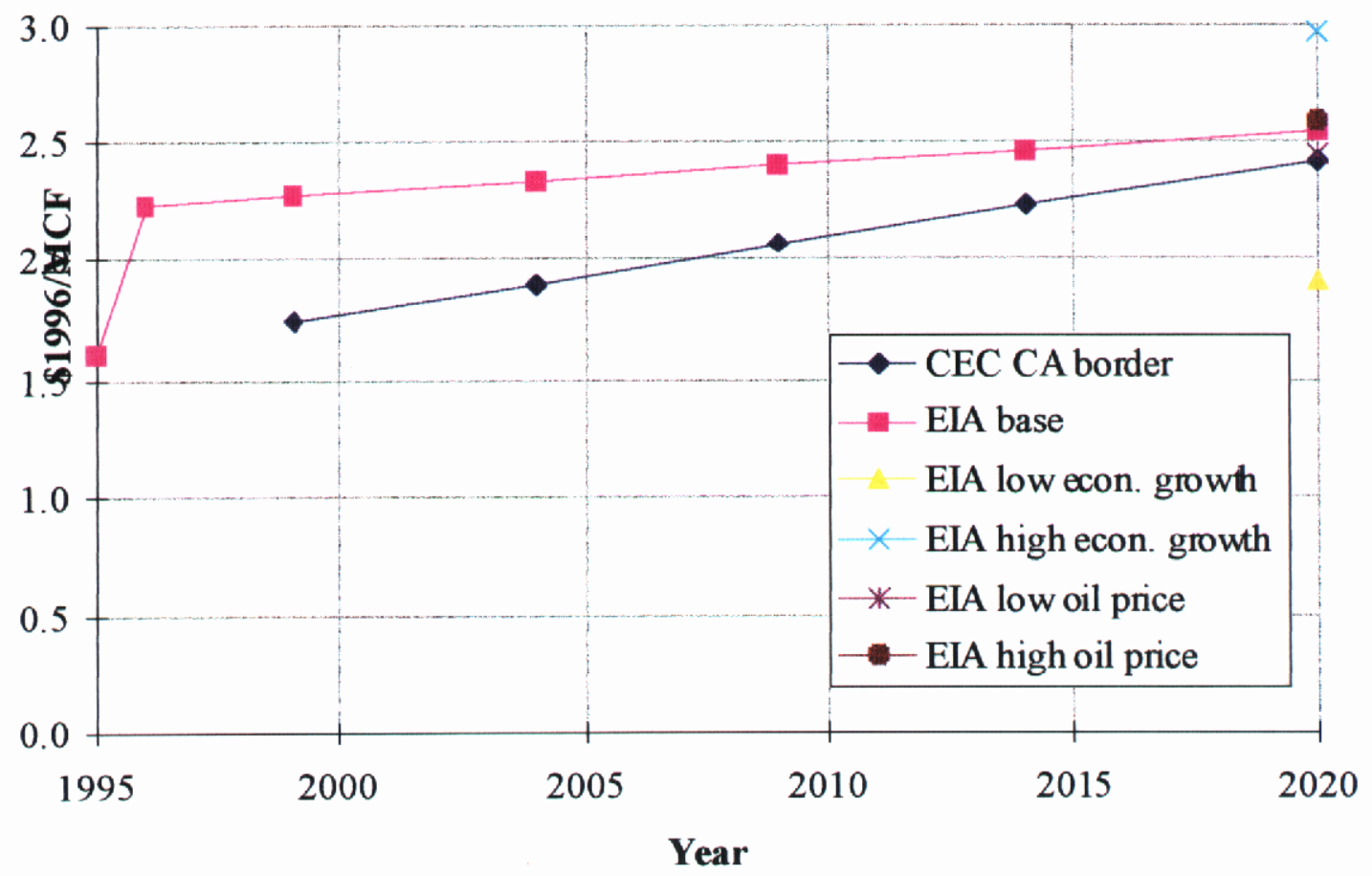

Figure 7.1 CEC and EIA Natural Gas Price Forecasts (\$/MCF)

Natural gas prices are expected to play a major role in the determination of electricity prices in the state of California. The current baseload generation technology of choice is the gas-fired combined cycle unit, and gas-fired simple-cycle combustion turbines typically used for peak load applications. In addition, natural gas is expected to be a major fuel source for fuel cells.

\section{Coal Prices}

U.S.-average minemouth coal prices for the base case, high, and low price scenarios are show in Table 7.2 [DOE-EIA 98a]. Coal prices as measured in 1996 dollars are expected to fall $39 \%$ in the next 24 years, from $\$ 18.50 /$ ton in 1996 to $\$ 13.28 /$ ton in 2020 . This is a real price deflation rate of $1.4 \%$ per year. The data in the table indicate that this real price decline is insensitive to the assumptions imposed for the scenarios.

Electricity from coal-fired plants competes with power from gas-fired combined cycle units in the market for baseload generation. Because natural gas prices are rising slightly and coal prices are dropping 
significantly, coal-fĩred units may eventually take market share for base load generation from gas-fired units.

Table 7.2 Coal Prices

\begin{tabular}{|c|c|}
\hline Year/Scenario & Coal price (\$/ton) \\
\hline 1995 & 19.25 \\
\hline 1996 & 18.50 \\
\hline 2020 Base case & 13.27 \\
\hline 2020/Low economic growth & 13.14 \\
\hline $2020 /$ High economic growth & 13.5 \\
\hline $2020 / \mathrm{Low}$ world oil price & 13.16 \\
\hline 20120/7igh world of price & 1328 \\
\hline
\end{tabular}

\section{Electricity Prices}

Electricity price forecasts for the base case are shown in Table 7.3 [Klein 97]. As indicated by the data in the table, average market clearing bulk power prices in California are expected to remain constant at $\$ 27 / \mathrm{MWh}$ through the year 2008 .

Table 7.3 Electricity Prices

\begin{tabular}{|c|c|c|c|}
\hline Year & $\$ 1998 / \mathrm{MWh}$ & Year & $\$ 1998 / \mathrm{MWh}$ \\
\hline $\mathbf{1 9 9 8}$ & 27.2 & $\mathbf{2 0 0 4}$ & 26.7 \\
1999 & 25.3 & $\mathbf{2 0 0 5}$ & 26.8 \\
$\mathbf{2 0 0 0}$ & 25.3 & $\mathbf{2 0 0 6}$ & 27.1 \\
$\mathbf{2 0 0 1}$ & 25.3 & $\mathbf{2 0 0 7}$ & 27.2 \\
$\mathbf{2 0 0 2}$ & 26.3 & $\mathbf{2 0 0 8}$ & 27.4 \\
$\mathbf{2 0 0 3}$ & 26.4 & & \\
\hline
\end{tabular}

Electricity prices will increase at times of higher load. The current annual and daily price profiles published by the California Power Exchange (PX) are assumed to persist for the foreseeable future. In addition, a competitive, interstate market for "replacement reserve power," as defined by the PX, is assumed to develop. It is further assumed that the price for replacement reserve power is not capped.

\section{ALR EMISSIONS BY SOURCE}

Base case carbon dioxide emissions by source are shown in Figure 8.1. The figure shows projected tons of carbon dioxide emissions per GWh by generation source for the year 2010 [CEC 94a]. The largest 
emitter, on a ton-per-GWh basis, is steam turbine distillate oil or residual oil at approximately 500 tons per GWh. The smallest emitter is solar technology, at 49 tons per GWh. These emissions are realized during the manufacture of solar power generation equipment.

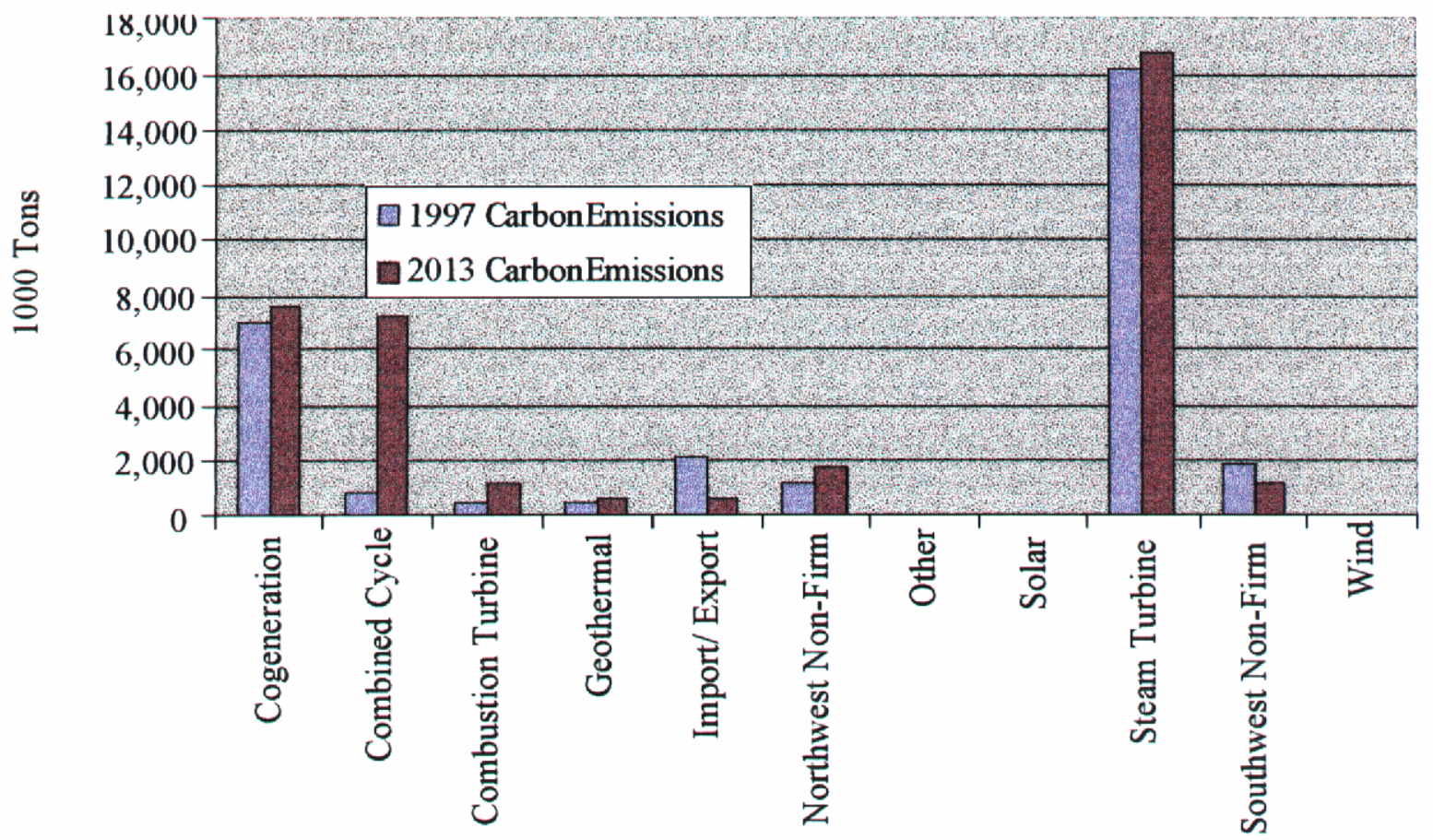

Figure 8.1 Projected Carbon Dioxide Emissions in 2010

Base case NOx and SOx emissions by source are shown in Figure 8.2 [CEC 94a]. The figure shows projected tons of NOx and SOx emissions per GWh by generation source for 2010. (Sources that emitted less than 0.1 tons per GWh were not included in this chart.) The largest emitter, on a ton-per-GWh basis, is steam turbine distillate oil or residual oil at approximately 7.5 tons per GWh, combined NOx and SOx. 




Figure 8.2 Projected NOx and SOx Emissions in 2010

\section{RELIABILITYAND RESERVE MARGINS}

For the base case, it is assumed that market prices are sufficient to stimulate the development of bulk generation capacity that will meet demand throughout the planning horizon. However, coordination and control of the system is assumed to be more complicated under deregulated markets.

System reliability and reserve margins are assumed to be established through competitive market mechanisms. It is assumed that high prices for replacement reserve power will stimulate the development and deployment of technologies that address this market need.

These technologies would supplement or replace current combustion turbine technologies that are used. In addition, it is assumed that interruptible tariffs, demand side management, and other real-time loadcontrol mechanisms will be needed to provide the ISO with the capability of controlling load. A need for flexible AC transmission systems (FACTS) is also assumed.

A perturbation of the base case is the degradation of system reliability due to the complexity of managing a deregulated market. It is assumed that financial or technical constraints prevent suppliers from meeting contractual obligations, and that outages ensue.

\section{COMPETITIVE MARKET PERFORMANCE/MARKET STRUCTURE}

For the base case scenario, the structure of the California electric power market is assumed to evolve in accordance with A.B. 1890. During peak hours, bulk electric power is assumed to be priced based on variable generation cost and capital recovery at the private sector cost of capital. During non-peak hours, electricity will be priced at the variable cost of production and private sector cost of capital for base-load plants. Current daily price profiles available from the Power Exchange (http:// www.calpx.com) are expected to persist for the near future. Transmission services will continue to be regulated by the FERC, 
managed by the Independent System Operator, and priced for full capital and operating expense recovery. Distribution services will continue to be regulated by the CPUC, managed by the local utilities, and priced for full capital and operating expense recovery. Time-of-day pricing will be available to most of the commercial and industrial class customers, and will be phased in for half of the residential class customers over the next 20 years. System reliability will be provided by interuptible contracts and standby generation controlled by ISO.

Oil, gas, coal, and other energy commodities will continue to be exchanged in a competitive market that reflects variable costs and full capital recovery at private sector costs. Several federal energy restructuring bills have been introduced by Congress that suggest mandatory quotas of electricity from renewable sources and price subsidies to help move renewables into the marketplace. Some bills promote a $20 \%$ renewable supply to the U.S. electricity grid by 2020 . Similarly, state utility restructuring bills, which are ahead of the federal legislation, provide subsidies over the short-term to help move renewables into the marketplace. It is assumed that renewables continue to be subsidized on some level that enables them to be within $30 \%$ of the conventional electricity fuel sources. Credits for emission reductions will be realized under existing emission trading programs. No carbon tax is assumed.

\section{STARE ECONOMIC GROWTH}

The U.S. Bureau of Economic Analysis (BEA) projects a compound annual growth rate of $1.6 \%$ for the period 1998 to 2045 for California. The first period, 1998-2000 shows the highest projection of $2.8 \%$, followed by the second highest period, 2000-2005, of $2.3 \%$. Then the BEA's projection drops below $2 \%$ for each remaining period. Figure 11.1 [BEA-97a] compares that with an illustrative LLNL lower and higher growth scenario. (Note that the BEA projection periods vary between 2 and 20 years) The LLNL lower growth scenario assumes a flat $1 \%$ compound annual growth rate in each period. The LLNL higher growth scenario replicates the BEA's high growth assumption until 2005, then, assumes that growth levels off to a $2 \%$ compound annual growth until 2045 instead of dropping below, as the BEA projects. The numbers used in this illustration are in Table 11.1 below.

Table 11.1 Gross State Product

\begin{tabular}{|c|c|c|c|}
\hline Year & $\begin{array}{c}\text { Gross State Product (in millions) } \\
\text { LLNL 2\% Growth After 2005 }\end{array}$ & $\begin{array}{c}\text { Gross State Product (in millions) } \\
\text { Base Case (BEA) }\end{array}$ & $\begin{array}{c}\text { Gross State Product (in millions) } \\
\text { LLNL Flat 1\% }\end{array}$ \\
\hline 1998 & 740,683 & 740,683 & 740,683 \\
\hline 2000 & 783,002 & 783,002 & 755,571 \\
\hline 2005 & 877,985 & 877,985 & 794,112 \\
\hline 2010 & 969,367 & 968,981 & 834,620 \\
\hline 2015 & $1,070,259$ & $1,051,693$ & 877,194 \\
\hline 2025 & $1,304,640$ & $1,200,560$ & 968,968 \\
\hline 2045 & $1,938,626$ & $1,601,057$ & $1,182,325$ \\
\hline
\end{tabular}




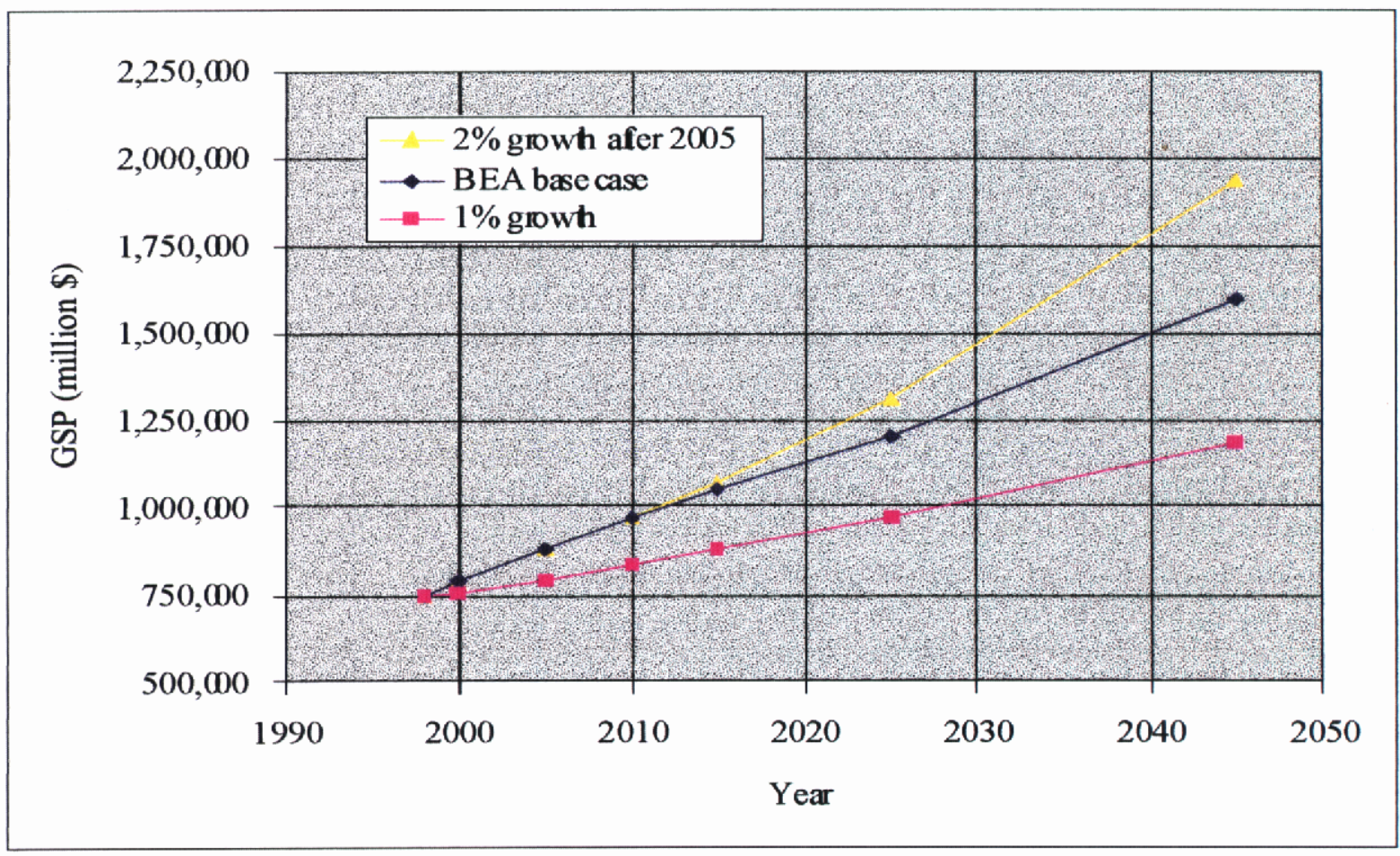

Figure 11.1 California GSP Forecast

\section{NUCLEAR POWER PLANT CLOSURES}

California's nuclear power plants have a combined capacity of 4310 MWe. They are currently scheduled to shut down 10 years prior to expiration of their operating licenses. These schedules are shown in Table 12.1 .

The level of uncertainty surrounding the actual closure of the plants is still high due to the difficulty in forecasting their profitability in a deregulated environment. There are two other possibilities facing these plants and the State: earlier closure or life extension.

If the operators of the plants elect to cease operation once stranded costs can no longer be collected (end of 2002) as a separate charge to consumers, the state could see a decrease of 4310 MWe from nuclear generation as soon as 2003 . There is also the possibility that some or all of the plants apply for life extension and operate 10 years beyond the original end-of-license period.

Table 12.1 Nuclear Plant Capacity and Closure Schedule

\begin{tabular}{|l|l|c|c|}
\hline Utility & Plant/Unit & Rating (MWe) & Current EOL \\
\hline Pacific Gas and Electric & Diablo Canyon 1 & 1073 & $7 / 1 / 15$ \\
& Diablo Canyon 2 & 1087 & $7 / 1 / 16$ \\
So. California Edison Company & San Onofre 2 & 1070 & $7 / 1 / 13$ \\
San Diego Gas and Electric & San Onofre 3 & 1080 & $7 / 2 / 13$ \\
\hline
\end{tabular}

The effect of either one of these scenarios will cause energy planners to alter their plans. If the plants close in 2002, the short notice may create a situation of undercapacity. This would cause sharp increases 
in prices an more imported electricity until more capacity is added on. If the plants are granted life extensions, other operators planning to take over that capacity will either have to cancel or postpone their plans.

\section{3. $\mathrm{CO}_{2}$ CONSTRAINTS}

The base case assumes there is no carbon tax or other constraint. A perturbation to this factor could assume a moderate $\mathrm{CO}_{2}$ tax at $\$ 50-\$ 75 /$ ton or a high tax at $\$ 150-\$ 200 /$ ton. In either case, the carbon tax helps make nuclear and renewables more desirable and could lead to extensions in nuclear plant licenses and increasing expansion of renewables in the state.

\section{GREEN ENERGY}

In the base case, customers will purchase the lowest-cost power, and will not make a major shift to green power. A perturbation to this scenario is that consumers make a conscious decision to pay more, up to $30 \%$ for green power. The market demand is unknown at the present time. Consumers are not well. informed and a variety of choices are now available. It may take a number of years and considerable data collection to see patterns of consumption here that match "green power" with willingness to pay higher prices.

In the industrial sector, selection of "green power" may never be a factor since industry tends to select the minimum-cost power. Nevertheless, data collection over a period of time will be telling. Other mitigating factors could be introduced such as policy incentives, public opinion, or even competition (e.g., "produced and manufactured by green power" as a marketing tool).

Consumers would also be willing to pay more for demand-side management products such as more efficient appliances, HVAC and lighting, and green building design, and construction services for residential and commercial construction. They are also willing to adopt the concept of local energy generation for the home or community to serve extra needed capacity and would like to be able to fuel their automobiles at home with either electricity of hydrogen generated from $\mathrm{H}_{2} \mathrm{O}$.

\section{ENERGY EFFICIENCY}

The energy use per dollar of gross state product appears to be very stable under the status quo growth prediction of a compound annual growth rate of $1.6 \%$. This implies that the economy and requisitc electricity generation are increasing at relatively the same rate. The perturbation for this parameter is that the statc cconomy either slows or grows at a faster rate while the electricity generation growth remains consistent. Figures 15.1 and 15.2 (BEA 97a) show the forecasted energy demands under the three economic scenarios listed in Section 11. 


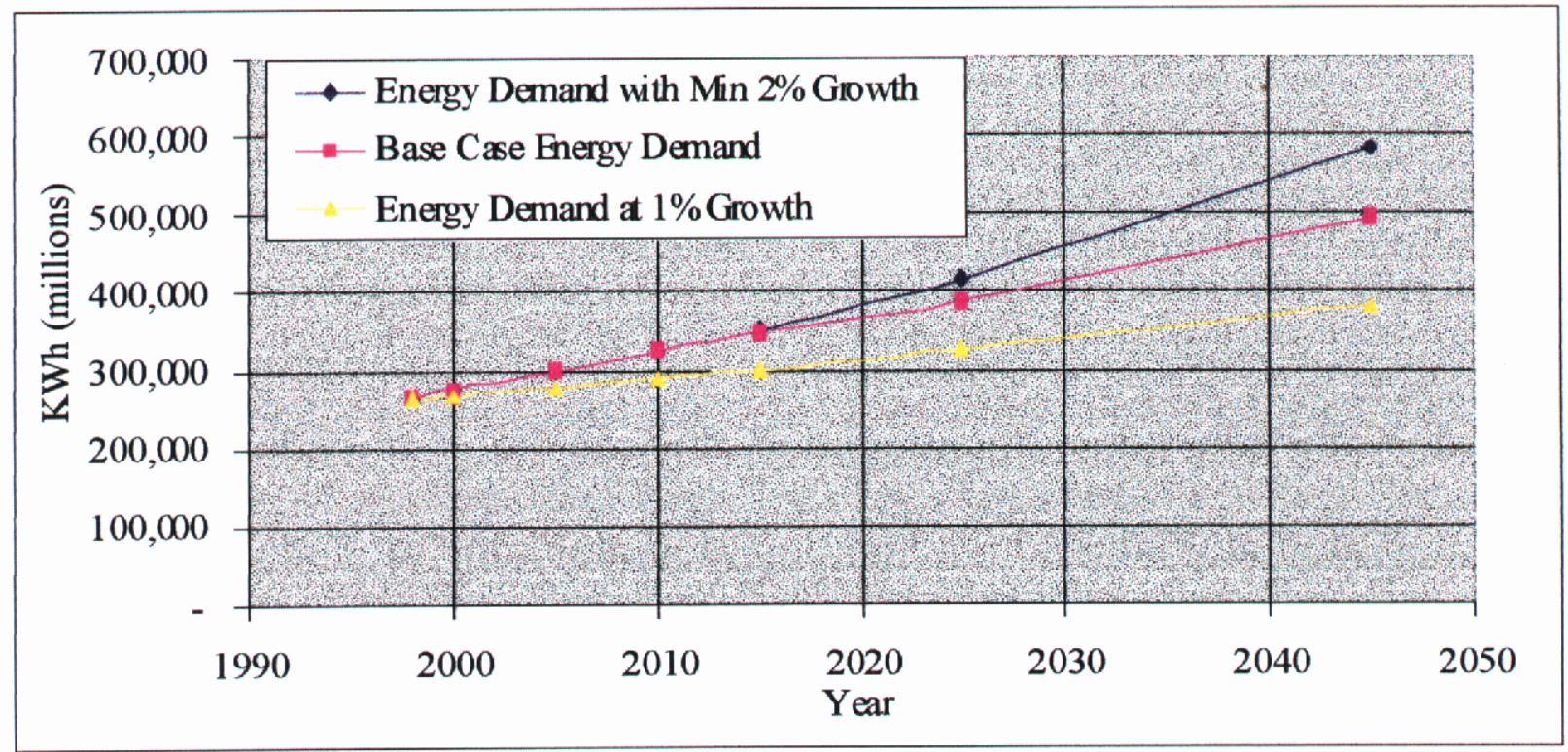

Figure 15.1 Energy Demand Forecast

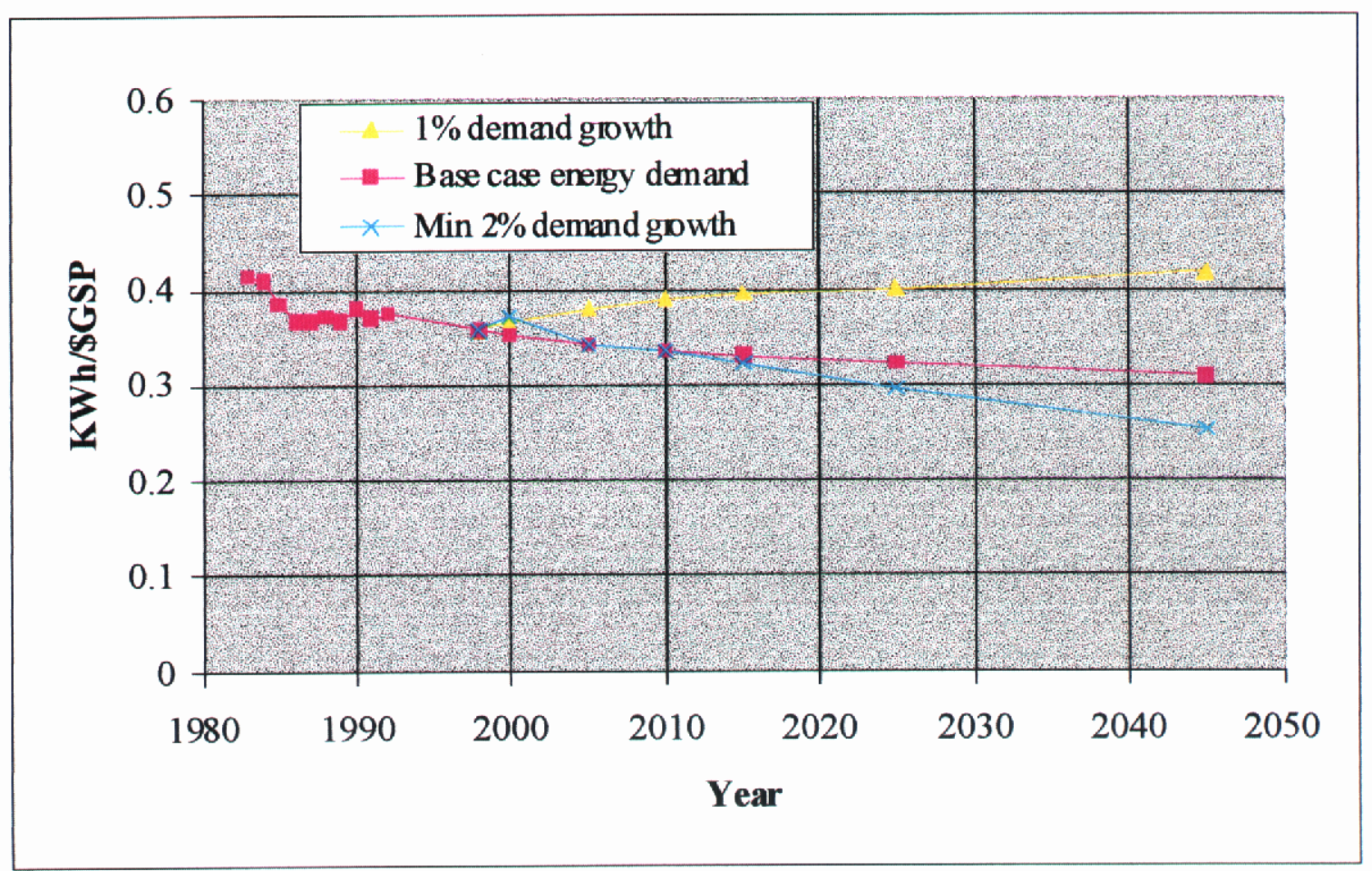

Figure 15.2 Energy Efficiency (KWh/\$GSP)

\section{PERTURBATION SCENARIOS}

The factors outlined in the previous fourteen sections provide a complete description of the base case scenario. In most of the discussions, perturbations about the base case values are suggested. These factor perturbations can be considered individually to generate simple perturbation scenarios. In addition, more complex perturbation scenarios can be defined by using combinations of perturbations of these factors. 
Four such scenarios are discussed below. These scenarios represent four plausible deviations about the base case, but do represent a comprehensive set of all possible energy futures.

\section{Low Economic Growh Scenario}

This scenario presumes a protracted reduction in the growth rate of the California economy. The following factors in the base case description are modified:

Electricity demand - The low demand growth scenario depicted in Figure 3.2 is realized (1\% annual growth rate).

Oil, Gas and Coal Demand - Because electricity demand is growing at a lower rate, new plant construction is deferred. The switch to natural gas generation depicted in Figure 3.3 is not as rapid.

Expected GSP Growth - The low growth perturbation of $1 \%$ per year is assumed.

Nuclear power plant operation - Nuclear power plants are assumed to shut down early, denying access to a low cost source of energy and capacity.

\section{High Natural Gas Prices Scemario}

This scenario assumes the current environment of low natural gas prices persists for a decade. All new generation constructed in the State during this period is natural gas-fired, and the State becomes highly reliant upon this energy source. After this initial period of low gas prices, natural gas prices cscalate rapidly (as was observed in the 1970s). The following factors in the base case description are modified:

Electricity Demand - Electricity demand follows the base case curve shown in Figure 3.2 until the year 2010. Then a transition is made to the low growth rate curve shown in the figure due to the higher natural gas prices in conjunction with the State's high reliance upon natural gas-fired generation.

Oil, Gas, and Coal Demand - Demand slowly shifts to fuels and renewable energy sources that can compete with natural gas at the higher prices. Overall demand will initially drop because plants that use other fuels are no longer operating and new ones will take time to build.

Oil, Gras, Coal and Electricity Prices - Relative prices of oil and coal will be low due to lower demand prior to the large natural gas price increase. However, oil and coal prices will increase as demand shifts from natural gas to oil and coal. Electricity prices will increase immediately with the natural gas price increase, and come down partially when other generation sources come on-line.

Air Pollution - Air pollution will increase as other fuels are introduced into the generating mix. Little investment would have taken place to control emissions from oil and coal. When the demand for these sources increases, air pollution will increase accordingly.

Expected GSP Growth - Over-reliance on natural gas or any single fuel source causes the State to be more vulnerable to cconomic slow down if its main source of energy experiences large price increases. Areas heavily dependent on electricity become less competitive with regions that have cheaper electricity, some industries relocate to areas with lower cost or more predictable electricity prices. New business choose to open in lower energy cost areas.

Nuclear Power Plant Closures - Nuclear plants shut down early, exacerbating the cost impact of high gas prices. 


\section{Dysfunctional Market Scenario}

Under this scenario, problems are encountered in implementing deregulation of the power market in. Califormia. The market is dominated by a few large suppliers, who manipulate the physical system and contractual agreements in order to gain a competitive advantage over smaller rivals. The complexity of managing the system overwhelms the ISO, and system reliability is degraded. The following factors in the base case description are modified:

State population by region - Under this scenario, it is assumed that population growth in the Central Valley is higher than that assumed in the base case scenario. This population shift leads to a higher air conditioning load relative to the base case. This air conditioning load occurs at system peak, which complicates system operation.

Electricity demand - Higher electric power demand growth is realized (2\% per year).

Load duration curve - A shift of population to the Central Valley from the coastal regions would tend to increase the peak-to-average ratio for the load. This would require more peak capacity, more coordination of generation scheduling, and more system dynamics. All of these factors tend to complicate system control.

High natural gas prices - Natural gas prices are higher than that expected in the base case. High natural gas prices favor more capital-intensive generating capacity such as coal and nuclear power. These capital intensive projects are only underlaken by the larger firms; market participation by smaller firms is limited. The higher natural gas prices also make use of simple-cycle gas fired units more expensive relative to base load coal-fired units. There is a shortage of these gas-fired units, which are typically used to provide generation during the system peak.

Competitive market performance/market structure - The few large suppliers strategically price and transmit power to inhibit entry of competitors. Bilateral power contracts of these few large suppliers are engineered to utilize transmission lines that would be needed by competitors entering the market. These large suppliers are assumed to price power above incremental production cost.

Nuclear power plants - Nuclear power plants are assumed to shut down before the end of their opcrating license. This removes $4300 \mathrm{MW}$ of generation from the State's generating pool.

\section{Preference for Green Power Scenario}

This scenario includes higher growth in energy demand in conjunction with a preference for green power and efficient end-use energy technologies. The following factors in the base case description are modified:

State Population by Region - The population of the state expands at higher growth rates in both urban and rural areas. The urban growth creates a need for more transmission and distribution corridors in congested areas as well as a demand for distributed renewable power. The growth in the rural areas, primarily the Central Valley, leads to higher air conditioning loads during system peak.

Load Duration Curve - The peak-to-average power ratio becomes larger, reflecting increased growth in areas with large cooling demands. This requires cheaper, more efficient peaking technologies or the ability to integrate the utilities with transportation to smooth the LDC.

Oil, Gas, and Coal Prices - Natural gas and oil prices increase at a higher than expected rate leading to the penetration of alternative fuel vehicles that can compete on a cost basis. In addition, the higher natural gas costs will make non-fossil electricity generation more competitive. 
Green Preference - There is a strong consumer demand for renewable energy and they are willing to pay a 20-30\% premium for clean, renewable energy. In addition, they are willing to purchase more demandside management goods and services for homes and offices. There is also a higher demand for highefficiency end-use energy technologies.

\section{DLUUSTRATION OF SCENARIO USAGE}

The base case scenario described in Sections 2 through 15 provides a common framework for cvaluating the importance of issue areas. For example, the Commission may need to evaluate the importance of early shutdown of nuclear reactors. To help evaluate the importance of addressing this issue, the Commission can compare the data describing total State consumption of electricity (Section 3) with nuclear generation capacity (Section 12). The magnitude of the impact of early nuclear plant shutdowns can be estimated and incorporated into the decision-making process. An initial ranking of issue areas under base case assumptions can be generated.

If a perturbation scenario were to be realized, some issue areas would be more important to have funded than others. For example, if a severe recession occurs in California, issue areas that address stimulating economic growth would be more important. Issue areas can be rated in terms of their contributions under the circumstances outlined in each of the four scenarios described previously. Table 17.1 lists some of the issue areas and their impacts under the scenarios. A " + " indicates that the issue area is more important under the scenario that it would be under the base case scenario.

Table 17.1 Scenario Impacts on Issue Areas

\begin{tabular}{|c|c|c|c|c|}
\hline Issue area & $\begin{array}{l}\text { Low economic } \\
\text { growth }\end{array}$ & $\begin{array}{l}\text { High natural } \\
\text { gas prices }\end{array}$ & $\begin{array}{l}\text { Dysfunctional } \\
\text { market }\end{array}$ & $\begin{array}{l}\text { Preference for } \\
\text { green power }\end{array}$ \\
\hline $\begin{array}{l}\text { Blogs - Design tools for } \\
\text { integrated buildings }\end{array}$ & + & + & & \\
\hline $\begin{array}{l}\text { Bldgs } 2 \text { - Study EE links to } \\
\text { quality and cost of } \\
\text { workplace }\end{array}$ & + & & & \\
\hline $\begin{array}{l}\text { IndT } A \text { heavy oil } \\
\text { processing }\end{array}$ & & + & & \\
\hline $\begin{array}{l}\text { Ind2 Smart technologies } \\
\text { for process control }\end{array}$ & + & + & + & \\
\hline $\begin{array}{l}\text { Thd3 Energy water } \\
\text { efficiency for electronics }\end{array}$ & & & & + \\
\hline $\begin{array}{l}\text { Ind4-Cold storage } \\
\text { technologies }\end{array}$ & + & & & \\
\hline $\begin{array}{l}\text { Envl Trdoor air quality in } \\
\text { EE blag design }\end{array}$ & & & & + \\
\hline $\begin{array}{l}\text { Env2- Wind energy, avian } \\
\text { mortality }\end{array}$ & & & & + \\
\hline
\end{tabular}

The data shown in the first row of T'able 17.1 indicate that if California were to experience low economic growth or high gas prices, it would be important to have design tools for integrated buildings available. This would lead to more efficient use of energy, making California more cost competitive or mitigating the impacts of a rapid increase in natural gas prices. Accordingly, a " + " is shown in each of these two scenario columns. These scores are for illustration only m actual scores would be provided by the CEC. 
The scenario impact data in Table 17.1 can be used to ensure that each of the four scenarios is addressed by funding issue areas. After issue areas are selected for funding under the base case scenario, a check can be made to ensure that at least one issue area that received a " $t$ " is funded for each of the four . scenarios. In the example data shown in Table 17.1, at least one of the four issue areas with a " $t$ " in the first column must be funded in order to ensure that the "Low economic growth" scenario has been addressed. In addition, issue area Ind2 proffers benefits to three of the four scenarios, so it would be a good area to invest $R \& D$ funds because it contributes under a wide range of circumstances. Moreover, it is the only issue area that contributes to the dysfunctional market scenario. For larger sets of issue areas that could not be evaluated by inspection in this manner, combinatorial optimization routines could be utilized to find the minimum set of issue areas that address all scenarios.

The data in Table 17.1 could also be used in a quantitative procedure to rank issue areas. One such procedure is as follows. First, assign numerical scores to each issue area under the base case scenario. This numerical score is an indicator of the degree to which the issue area achieves the five PIER objectives. Next, modify scores of issue areas by increasing the issue area score (by perhaps $25 \%$ ) if there is a " $t$ " in the row for that issuc area and column for that scenario. Assign weights to each scenario, possibly 0.6 for the base case and 0.1 for each of the 4 perturbation scenarios, and take the weighted average score under the five scenarios. Rank the issue areas using this weighted score, and fund the highest-scoring issue areas until tunding is exhausted. More comprehensive scenario analysis techniques could also be employed if a quantitative decision framework were implemented.

Finally, it is important to note that the private sector may fund $R \& D$ activitics that address CEC issue areas. Because private sector organizations tend to have shorter time horizons and may be less willing to fund R\&D that address low-probability events, State R\&D funding may be more effectively utilized if it is channeled into $R \& D$ that would provide longer-term payoffs and would address low probability events. Consequently, it may be more important for CEC to fund the issue areas that contribute the most under the perturbation scenarios than those that contribute under the base case, or most likely case. 


\section{REFERENCES}

BEA 97a - Projections of Employment, Income, and GSP, 1969-2045. Bureau of Economic Analysis Regional Accounts Data, December 4, 1997.

CDWR 98 - California Department of Water Resources: Bulletin 160-98: California Water Plan, January 1998.

CEC $94 a$ - ER 94 systcm planning study (ELFIN).

CEC 96a - California Energy Commission Hourly Load Duration Curves for 1996.

CEC 97 a - California Energy Commission, Staff's Revised Forecast of Natural Gas Production and Wellhead Prices, Docket 96-FR-1, August 14, 1997.

CEC $97 \mathrm{~b}$ - Staff's Revised Forecast of Natural Gas Production and Wellhead Prices. Fuel Resources Office, California Energy Commission, July 30, 1997.

CEC 98a - California Energy Commission Database, Multisector Enduse, End Use Energy in Trillion BTUs.

CEC 98b - Califomia Energy Commission Database, California Electrical Energy Generation 1988 to 1997 (Table .I-11).

CEC 98c - Multi-Sector Online Database, July 29, 1998.

DOE-EIA 98 - Department of Energy - Energy Information Administration, Annual Energy Outlook 1998.

DRI 98 - Quest Custom Report, California Population by County, California Energy Commission.

Klein 97 - Klein, Joel B., Interim Staff Market Clearing Price Forecast for the California Energy Market: Forecast Methodology and Analytical Issues, California Energy Commission, December 10, 1997. 